\title{
Seismotectonics of the Chersky Seismic Belt, eastern Sakha Republic (Yakutia) and Magadan District, Russia
}

\author{
K. Fujita ${ }^{1}$, B. M. Koz'min ${ }^{2}$, K. G. Mackey ${ }^{1}$, S. A. Riegel ${ }^{1, *}$, M. S. McLean ${ }^{1, * *}$, and V. S. Imaev ${ }^{2, * * *}$ \\ ${ }^{1}$ Department of Geological Sciences, Michigan State University, East Lansing, MI 48824, USA \\ ${ }^{2}$ Institute of Diamonds and Precious Metal Geology, Siberian Division, Russian Academy of Sciences, 39 Lenin Prospekt, \\ Yakutsk, Sakha Republic (Yakutia), 677891, Russia \\ * now at: Joint Functional Component Command for Space, Vandenberg Air Force Base, CA 93437, USA \\ *** now at: SubTerra, Inc., 218 East North Bend Way, North Bend, WA 98045, USA \\ **** now at: Institute of the Earth's Crust, Siberian Division, Russian Academy of Sciences, 128 Lermontova, \\ Irkutsk 664033, Russia
}

\begin{abstract}
The Chersky seismic belt represents a zone of deformation between the North American and Eurasian plates in northeast Russia. The belt extends from the Laptev Sea into the Chersky Range where it splits into two branches. One branch extends to Kamchatka and the Aleutian-Kurile Junction, while the other branch extends south towards Sakhalin Island. Focal mechanisms indicate a change from extension to transpression in the northern Verkhoyansk Range and generally left-lateral transpression in the Chersky Range extending to northern Kamchatka. The few focal mechanisms on the second branch suggest rightlateral transpression. A large number of faults, sub-parallel to the seismicity and presumed to be strike-slip, are visible in satellite imagery and topographic maps and are also associated with seismically generated landslides.

These data support a model in which the Sea of Okhotsk forms the core of a separate Okhotsk microplate surrounded by diffuse boundaries on the north and west. Microseismicity in continental northeast Russia is most heavily concentrated within and between the fault systems along the northern boundary of the proposed Okhotsk plate and indicates a high level of deformation. The sense of slip on the faults (both from focal mechanisms and geology) are also generally consistent with the extrusion of the Okhotsk plate to the southeast as it is compressed between its larger neighbors. The northernmost part of the Okhotsk plate may be decoupled to some degree from the more stable central Sea of Okhotsk.
\end{abstract}

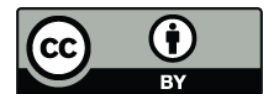

Correspondence to: K. Fujita (fujita@msu.edu)

\section{Introduction}

Continental intraplate regions are known to have considerable complexities with the presence of numerous blocks or microplates and wide zones of diffuse deformation (e.g., Jackson and McKenzie, 1988; England and Jackson, 1989; Gordon, 1998). If they maintain some or all of their rigidity, these microplates may be "extruded" or take part in "escape tectonics" as has been suggested in the cases of Turkey and the Himalayan collision (e.g., Tapponnier et al., 1982; Şengör et al., 1985). One of the most poorly understood intracontinental convergent plate boundaries lies in northeastern Russia (here defined as the area covered in Fig. 1 north of about $58^{\circ} \mathrm{N}$ ) between the North American and Eurasian plates, within a broad zone of seismic activity known as the Chersky Seismic Belt (CSB, Fig. 2; Parfenov et al., 1988).

The plate tectonic configuration of north- and far-eastern Russia (Fig. 1, inset) has been studied by numerous workers, with debate centering on the location of the North AmericaEurasia boundary. From the Laptev Sea, some workers (e.g., Chapman and Solomon, 1976; DeMets, 1992; Steblov et al., 2003) favor extending the North America-Eurasia boundary south across northeast Russia to join with the seismicity of Sakhalin Island, then on to northern Japan, attaching the Okhotsk region to the North American plate. Others (e.g., Zonenshayn et al., 1978; Savostin and Karasik, 1981; Cook et al., 1986; Parfenov et al., 1988; Fujita et al., 1990a, 1997; Riegel et al., 1993; Seno et al., 1996) prefer to have the North America boundary follow the band of earthquakes along the Chersky Range to northern Kamchatka and suggest that the Sea of Okhotsk, Kamchatka, northern Japan, eastern Sakhalin, and the area around Magadan comprise a separate Okhotsk microplate or block. 


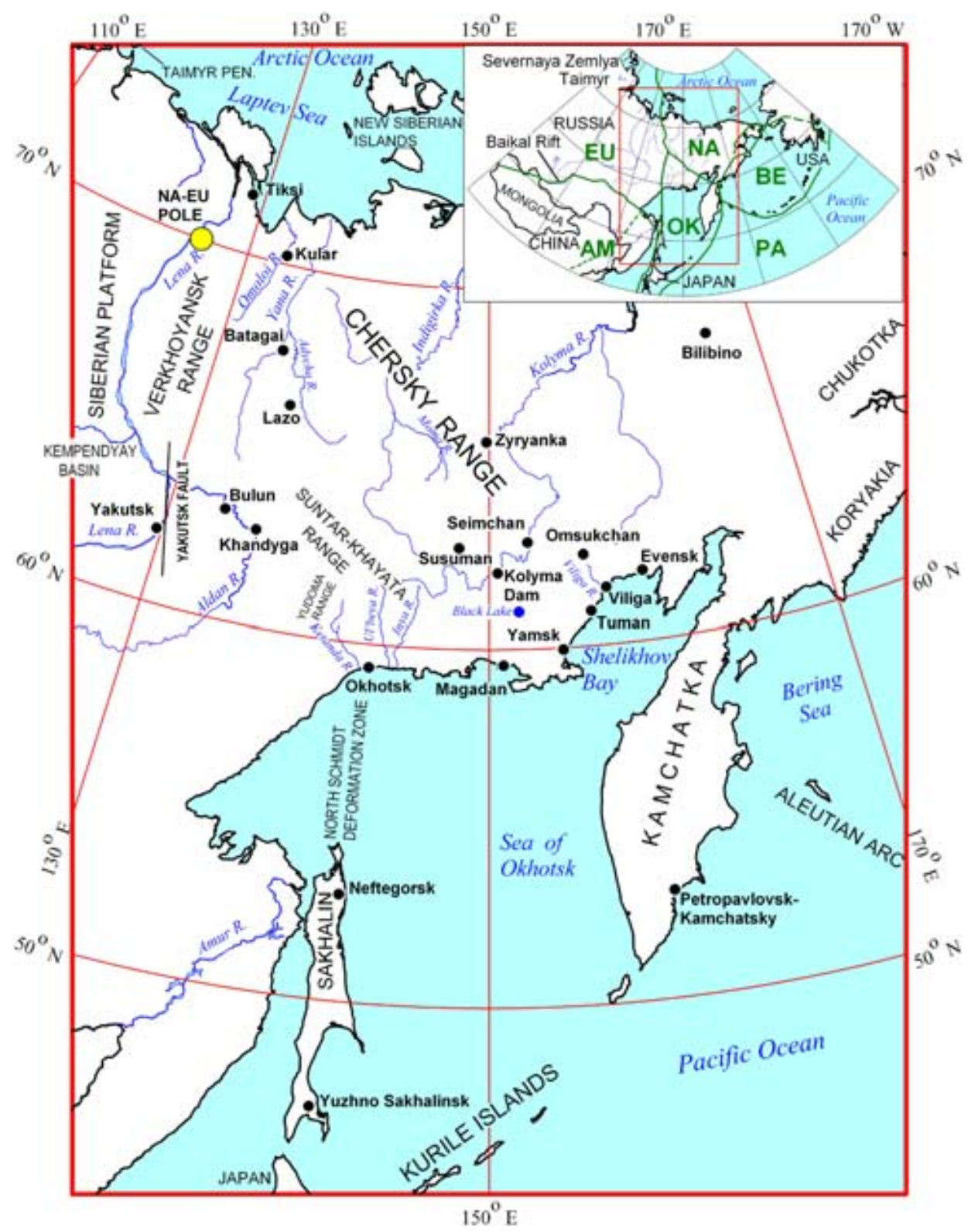

Fig. 1. Index map of northeast Russia showing major geographic localities mentioned in the text. Upper inset shows simplified plate map and location of this figure. Plate abbreviations in inset are NA - North America, BE - Bering, EU - Eurasia, AM - Amur, OK - Okhotsk, and PA - Pacific. North America - Eurasia Euler pole is shown by yellow dot.

The present-day geodynamics of northeast Asia is controlled by the interactions of the Eurasian, North American, and Pacific plates (Fig. 1 inset; Cook et al., 1986; Parfenov et al., 1988; Fujita et al., 1990a, 1997), and possibly the presumed far-field effects of the Indian plate (e.g., Peltzer and Tapponnier, 1988; Worrall et al., 1996). The movement of these giant plates with respect to each other has resulted in the development of diffuse seismic zones between them and the apparent formation of at least three independent blocks or microplates (Fig. 1, inset): Okhotsk (Savostin et al., 1983;
Cook et al., 1986; Riegel et al., 1993; Seno et al., 1996), Amur (Savostin and Baranov, 1981; Savostin et al., 1983; Heki et al., 1999), and Bering (Mackey et al., 1997).

The boundary zone between the North American and Eurasian plates in the Arctic and northeast Asia is clearly defined by a $3500 \mathrm{~km}$ long belt of earthquakes that extends from the northern termination of the Mid-Atlantic Ridge to the Kamchatka Peninsula and northern Japan (Fig. 2; Tarr, 1970; Savostin and Karasik, 1981; Cook et al., 1986; Parfenov et al., 1988; Imaev et al., 1990; Fujita et al., 1990a). 


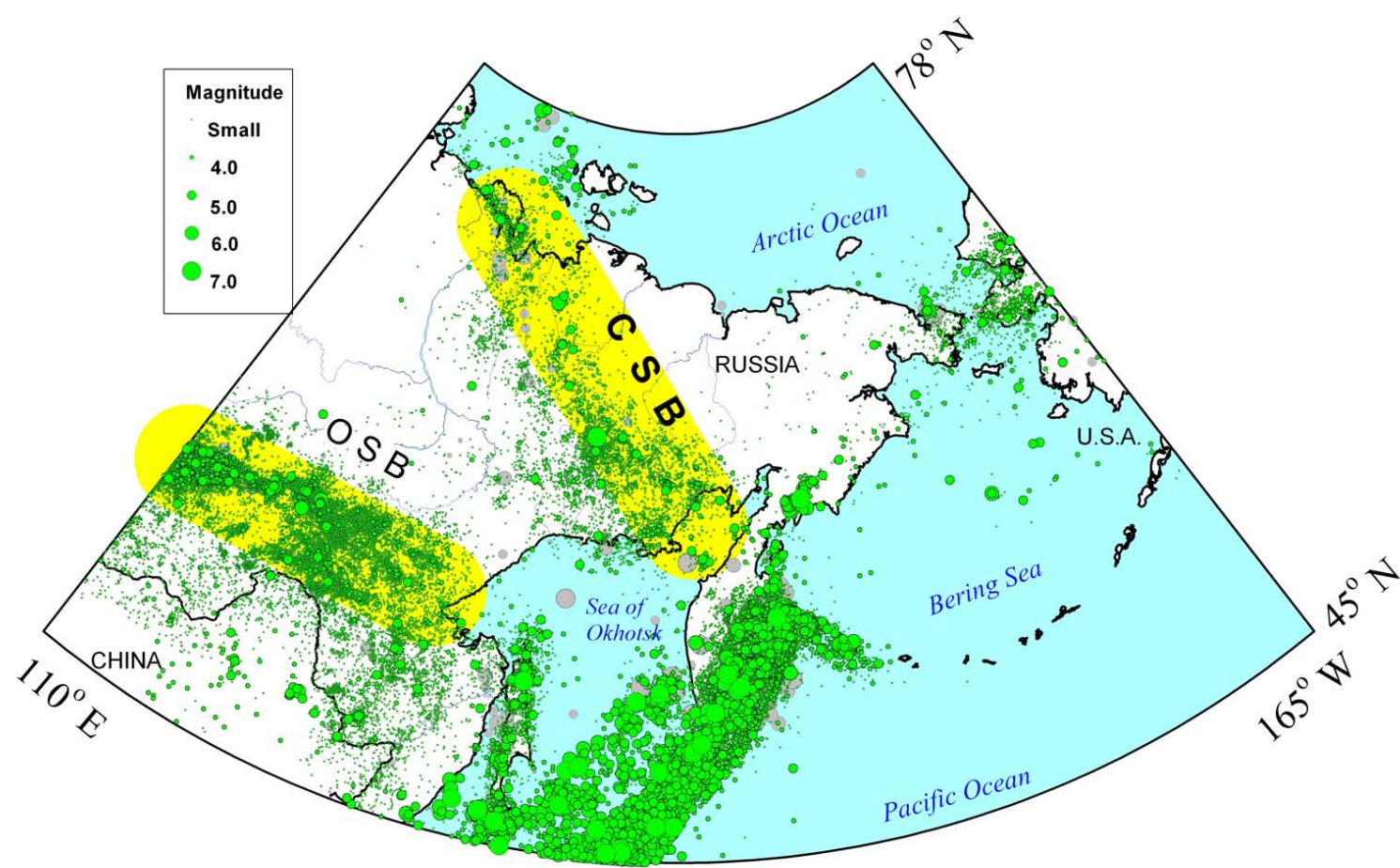

Fig. 2. Seismicity map of eastern Russia based on MSU Eastern Russia Seismicity Database. Events in the Aleutian Islands are not included in the database and are not shown. Dots are proportional to event size. Older events (pre-1960) are shown as grey dots without outline. The locations of the Chersky Seismic Belt (CSB) and Olekma-Stanovoi Belt (OSB) are shown in yellow shading.

In the Arctic Ocean, the seismicity forms a narrow band of primarily normal faulting earthquakes along the Arctic (Gakkel) Mid-Ocean Ridge (Savostin and Karasik, 1981; Cook et al., 1986; Jemsek et al., 1986; Fujita et al., 1990a; Avetisov, 1996), which represents the locus of sea-floor spreading (e.g., Wilson, 1963; Vogt et al., 1979; Cochran et al., 2003). As the boundary crosses onto the Asian continental shelf, the band of epicenters becomes diffuse and broadens to cover much of the Laptev Sea (Fujita et al., 1990b; Avetisov, 1996).

A unique aspect of the CSB is that the pole of rotation between the North American and Eurasian plates lies within it. Although geophysical and geodetic data sets have yielded somewhat different locations for the North America-Eurasia pole of rotation (Minster et al., 1974; Cook et al. 1986; DeMets et al., 1990; Argus and Heflin, 1995; Imaev et al., 2000; Kogan et al., 2000; Sella et al., 2002), all of them place the pole close to the plate boundary near the southern end of the Laptev Sea. This implies that there is extension in the Laptev Sea and convergence in the CSB and the Sea of Okhotsk region, a possibility first recognized by Wilson (1963).

There are multiple theories on how the convergence south of the pole of the rotation is accommodated. Since the core of the Sea of Okhotsk appears to be aseismic, but surrounded by zones of seismicity, it has been proposed that there is an independent Okhotsk plate that is being extruded to the southeast (Cook et al., 1986, Riegel et al., 1993; Fujita et al., 1997). Large strike-slip faults striking along and parallel to the proposed North America - Okhotsk plate boundary (Gusev, 1979; Smirnov, 2000; Imaev et al., 1994) also support this conclusion (discussed further below). The northern boundary of the plate is formed by a broad, diffuse zone of seismicity (Koz'min, 1984; Imaev et al., 1990, 2000; Mackey et al., 2005) indicating that the region is actively deforming. Models for this deformation range from distributed deformation and thrusting within the northwestern Okhotsk plate (e.g., Bobrovnikov and Izmailov, 1989), to rigid extrusion of the entire plate (e.g., Riegel et al., 1993), and various combinations thereof (Hindle et al., 2006, 2009, this volume).

Previous studies of the seismicity and seismotectonics of northeast Russia have been limited by the lack of access to regional seismic arrival time and $\mathrm{P}$-wave first motion data. The generally small size of events has resulted in poor hypocentral locations and few reliable focal mechanism or moment tensor solutions. As part of a long-term cooperative research program between Michigan State University (MSU), the University of Alaska-Fairbanks (UAF), the Institute of Diamond and Precious Metal Geology (formerly the Yakutian Institute of Geological Sciences), and the Magadan and Yakut affiliates of the Geophysical Survey of the Russian Academy of Sciences (formerly Magadan and Yakut Experimental Methodological Seismological Divisions), we have been able to combine previously unavailable Russian data, 
including material from analog seismograms, seismicity catalogs and bulletins, and first motion data, with data from the World Wide Standardized Seismograph Network (WWSSN), the UAF seismic network, and other western data sets to study this enigmatic region.

In this paper, we reexamine seismicity data and focal mechanism solutions for the larger earthquakes of the CSB using all available seismological data, as well as data from Russian field studies, satellite imagery, and topographic maps, to examine the nature of the plate boundary in northeast Asia. These data appear to be consistent with the southeastward extrusion of an Okhotsk plate to accommodate the convergence between the North American and Eurasian plates.

\section{Seismic stations and recording}

Since the Soviet era, the study and recording of earthquakes in eastern Russia has been assigned to various regional networks. The first stations in northeast Russia were deployed at Yuzhno Sakhalinsk (1947), PetropavlovskKamchatsky (1951), Magadan (1952), Tiksi (1956), and Yakutsk (1957) by the Academy of Sciences of the USSR (Fig. 1). Starting in the early 1960s, the Yakutian Institute of Geological Sciences and the Yakut Experimental Methodological Seismological Division (EMSD) of the Siberian Division of the Academy of Sciences of the USSR deployed a network with stations in the seismically active parts of the Yakut ASSR, now Sakha Republic (Yakutia). By 1980, the Yakut regional network was composed of 12 seismic stations, and the network reached its peak in 1990 when 22 stations were operating (Fig. 3). Subsequently, due to financial difficulties, the number of seismic stations declined to 11 in the mid-1990s. The network was again expanded in the early 2000s. The Magadan regional network was operated by the Magadan EMSD and the Northeast Interdisciplinary Research Institute of the Far Eastern Division of the Academy of Sciences of the USSR. The first regional stations were deployed in 1967 and the network expanded to include Chukotka in the 1980s. The Magadan network also suffered from the collapse of the USSR, recovering in the early 2000s.

All stations initially used analog recording and were equipped with Russian short-period instruments such as the SKM-3 seismometers and produced recordings on photographic paper. Starting in 1991, in cooperation with MSU and the Geophysical Institute of the UAF, PC-based digital recording systems were installed in Yakutsk and Batagai. In 1993, Streckeisen STS-1 instruments were deployed at Yakutsk and Magadan as part of the Incorporated Research Institutions for Seismology Global Digital Seismographic Network (GSN). Tiksi and Bilibino became GSN stations in 1995. Additional PC-based digital systems were deployed starting in 1999 in both the Sakha Republic (Yakutia) and the Magadan District, many of which were in con- junction with MSU. Temporary stations were also deployed in the CSB after the 1971 Artyk earthquake, as well as after more recent events near Magadan.

Hypocentral parameters were initially determined graphically using only regional $\mathrm{P}$ - and S-arrival times and regional travel-time curves. In general, data were not shared between networks, although some data were taken from bulletins of adjacent networks. Epicentral location errors have varied and ranged from 5 to $50 \mathrm{~km}$ depending on date and location, though since 1970, the seismic networks have usually had a sufficient number of stations deployed such that epicenters are of moderately good quality, with errors generally less than $20 \mathrm{~km}$ (Fig. 3). Focal depths were calculated from a hyperbolic travel-time curve for $\mathrm{P}$ - and $\mathrm{S}$-waves recorded at distances of less than $50 \mathrm{~km}$ from the epicenter or from the misfit of the graphical determinations. Starting in the early 1990s in the Magadan network, and around 2000 in the Yakut network, hypocenters were calculated numerically using regionally derived travel-time curves (Mackey, 1999). The size of events is regionally calculated in terms of energy class (K class; see Rautian et al., 2007), using the graphical relationships of Rautian (1958). Larger events have been relocated using combined regional (including adjacent networks) and teleseismic data by Mackey (1999) and Mackey and Fujita (2000).

The Magadan and Yakutsk networks have located over 10000 earthquakes from the CSB. The completeness of seismicity data has varied with the number of operational stations and sensitivity of the recording equipment, as well as the proximity to the network boundaries. In 1990-1991, when the networks were at their height, all seismic events with $K \geq 8\left(m_{b} \approx 2.5-3.0\right)$ are believed to have been recorded throughout most of the CSB (Artamonov and Mishina, 1984) except in the Laptev Sea; the completeness threshold for the Laptev Sea shelf was $K \geq 10$. In general, the networks existing in 1990-1991 recorded all events in the northeast USSR with $K \geq 11\left(m_{b}>4\right)$. After some of the stations were closed, the completeness threshold increased. In the mid-1990s, the completeness threshold in the CSB was about $K \geq 11$, and for all of Yakutia, $K \geq 12\left(m_{b}>4.5\right)$. The teleseismic completeness threshold at the beginning of the 21st century is about magnitude 4.0-4.5 in northeast Asia.

\section{Seismicity}

The seismicity map of eastern Russia (Fig. 2; Mackey et al., 2005) is based on the MSU Northeast Russia seismic database (Mackey and Fujita, 1999) that was compiled by combining data from Russian and western sources. Primary Russian sources include the annual Zemletryasenia v SSSR (Earthquakes of the USSR) and its successor publication Zemletryasenia Severnoi Evrazii (Earthquakes of Northern Eurasia), the district-wide seismological catalogs Materialy po Seismichnost' Sibiri (Data on the Seismicity of Siberia) 


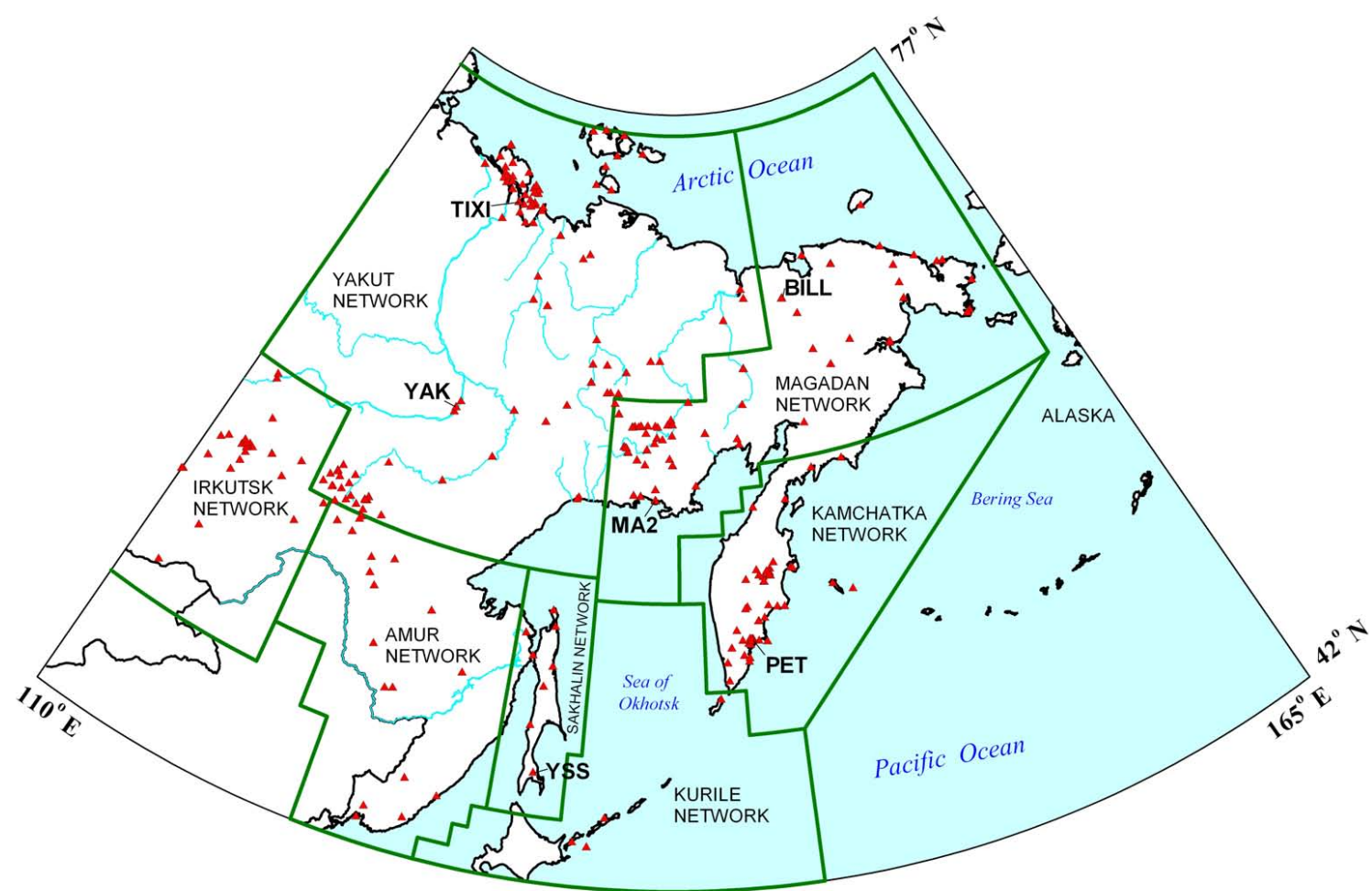

Fig. 3. Seismic networks and stations that have operated in eastern Russia 1960-2006. Seismic stations are shown as red triangles; not all stations operated concurrently. The network boundaries roughly correspond to political subdivisions mentioned in the text. The Yakut network corresponds to the Sakha Republic (Yakutia), the Magadan network corresponds to the Magadan district (southwestern part of the network) and the Chukchi Autonomous District (northwestern part of the network). IRIS Global Seismic network stations are labeled: YAK - Yakutsk; PET - Petropavlovsk-Kamchatsky; MA2 - Magadan; BILL - Bilibino; and TIXI - Tiksi.

and Seismicheskii Byulleten' Dal'nego Vostoka (Seismic Bulletin of the Far East), and unpublished network bulletins of the Yakut, Baikal, Magadan, and Kamchatka regional seismic networks. Western sources include the International Seismological Summary and the International Seismological Center Bulletin, the data files of the National Earthquake Information Center (USGS), the UAF Western Alaska Network catalog (Biswas et al., 1983), and the Alaska Earthquake Information Center. Teleseismic events are shown from 1735 to the present and microseismicity from 1964 to 2004 .

The CSB proper (Fig. 2) is defined as the broad zone of shallow seismicity which extends approximately $1800 \mathrm{~km}$ from the termination of the Arctic Mid-Ocean Ridge in the northern Laptev Sea, through the Chersky Range, to the Kamchatka Peninsula (Fig. 1). Seismicity continues further to the Aleutian-Kamchatka arc-arc intersection. Almost all seismic activity in continental northern and far-eastern Russia is confined to the CSB, the Olekma-Stanovoi belt (OSB, Fig. 2; Parfenov et al., 1985, 1987) extending eastward from the Baikal rift zone, Sakhalin Island (e.g., Solov'ev et al., 1967), Koryakia, and eastern Chukotka (Fujita et al., 2002a; Mackey et al., 2009, this volume). The center of the Sea of Okhotsk, western Chukotka, and the Siberian platform are essentially devoid of shallow earthquakes.
Only a few large earthquakes (12 February $1951, M=6.4$; 14 April 1951, $M=6.5$; 18 May 1971, $M_{w}=6.4$ ) have occurred in the CSB during the instrumental era, with teleseismic activity dominated by small to medium-sized events ( $\left.m_{b} 4-6\right)$. Most of the $m_{b}>5.0$ events in the Chersky Range form a lineation along the northern edge of the belt (Fig. 2), extending from just south of the Laptev Sea $\left(\sim 70^{\circ} \mathrm{N}, 139^{\circ} \mathrm{E}\right)$ south to the central Chersky Range $\left(\sim 64^{\circ} \mathrm{N}, 146^{\circ} \mathrm{E}\right)$, then across to Shelikhov Bay and to northern Kamchatka. The east coast of Kamchatka, north of the Aleutian-Kamchatka arc-arc junction, is also very active. Here, a north-trending belt of events connects the eastern end of the CSB with the seismicity of the Aleutian and Kamchatka arcs. The region is beyond the scope of this paper and has been described in part by Zobin and Simbireva (1977), Bourgeois et al. (2006), Pedoja et al. (2006) and others.

A second, weaker lineation of earthquakes extends from the central Chersky Range southward through the SuntarKhayata Range (Fig. 1). The projection of this trend extends towards Sakhalin Island, and it is along this alignment that some workers (Chapman and Solomon, 1976; DeMets, 1992) place the North America-Eurasia plate boundary. However, there is a distinct gap in seismicity in the western Sea of Okhotsk north of Sakhalin along this proposed plate 
boundary (Fig. 2). Although the lack of microseismicity may be due to location procedures and/or poor regional station coverage, the lack of teleseisms in the gap between about $55.5^{\circ}$ and $60^{\circ} \mathrm{N}$ is also striking. In 2000, we installed a seismic station in Okhotsk; however we have not recorded any events that can be located in this gap. Further south, Sakhalin and northwestern Hokkaido, Japan, are extremely seismically active and include such events as the $M_{w}=7.0$ Neftegorsk earthquake of 1995 (Ivashchenko et al., 1995).

The CSB can be subdivided into five segments, discussed separately below, with different tectonic styles: the Laptev segment on the shelf of the Laptev Sea; the Northern Verkhoyansk segment between the Lena River delta and Yana River; the Chersky segment extending from the lower course of the Yana River, through the Chersky Range, to the Sea of Okhotsk; the Okhotsk Coastal segment along the northern coast of the Sea of Okhotsk; and the Ketanda segment in the Suntar Khayata and Yudoma Ranges (Fig. 1), which branches off from the Chersky segment. Each of these segments can be further subdivided into one or more seismic zones.

All well-determined focal depths within the CSB are shallow, less than $25 \mathrm{~km}$, and crustal (McMullen, 1985; Jemsek et al., 1986; Cook, 1988, Olson, 1990; Riegel, 1994, Global CMT Catalog, 2008). Crustal thickness varies from about $20 \mathrm{~km}$ or less (Laptev Sea region) to greater than $40 \mathrm{~km}$ beneath the Siberian platform (Suvorov and Kornilova, 1986; Mackey et al., 1998).

There is also considerable explosion contamination of the Russian seismicity catalog with industrial explosions, especially near placer gold mining districts (Godzikovskaya, 1995, 2000; Odinets, 1996; Mackey, 1999; Mackey and Fujita, 1999; Mackey et al., 2003a). Using the temporal distribution of events, Mackey et al. (2003a) have identified areas of explosion contamination in the Sakha Republic (Yakutia) and the Magadan district associated with placer mining in the lower Yana region, prospecting operations near the Lena River delta and at Lazo, coal and placer mines near Susuman, and construction of the Kolyma dam (Fig. 1). The inclusion of explosions can bias the interpretation of natural seismicity. However, in the CSB region, the contamination is relatively minor and does not significantly impact mapped natural seismicity trends, although it is more significant elsewhere (Godzikovskaya, 2000; Mackey et al., 2003a).

\section{Focal mechanisms}

Focal mechanisms for earthquakes in the CSB have previously been determined by a number of authors (e.g., Savostin and Karasik, 1981; Koz'min, 1984; Franke et al., 2000) using P-wave first motions (e.g., Stauder, 1962), synthetic seismograms (e.g., Stein and Kroeger, 1980), surface wave radiation pattern analysis (e.g., Stein, 1978), and centroid moment tensors (CMT, Dziewonski et al., 1981). Early Soviet
P-wave first motion mechanisms (e.g., Balakina et al., 1972) are often less-reliable, having used bulletin-reported data for both teleseismic and regional stations.

We determined or redetermined focal mechanism solutions using data acquired as part of the collaborative program, primarily using a combination of regional and teleseismic first motion data and teleseismic synthetic seismogram modeling. First motion data were obtained from rereading records of the WWSSN and Yakut, Magadan, and Alaska regional networks, supplemented by first motions from the ISC and Russian operational bulletins. Synthetic seismograms of WWSSN records were generated by forward modeling using the algorithm of Kroeger (1987), which incorporates all significant reflections and conversions from a specified nearsource crustal structure. The final crustal model and source parameters, which we show in the figures, are those which provided a subjectively acceptable fit to the observed data. Some of the events examined proved difficult to model, and depth phases often resulted in apparent variations in focal depth on the order of a kilometer for different stations for the same event; this is probably due to a combination of variable sediment thickness and reflections from irregular topography in the source region. In areas such as the Laptev Sea, where there are generally more uniform, flat-lying layers of sediments, much better waveform fits were obtained.

In this paper we also incorporate the results of other published and unpublished Russian solutions and best-fitting double couple CMT solutions (Global CMT Catalog, 2008, formerly Harvard CMT Catalog). Table 1 summarizes the preferred focal mechanisms for events in the CSB that are plotted in the regional seismicity figures. When multiple solutions were available for an event, the preferred solution was selected generally on the basis of the following ranking of methodology (from high to low weight): Waveform modeling and moment tensors, Rayleigh wave radiation patterns, Pwave first motions read by the authors, and bulletin reported P-wave first motions. For P-wave and Rayleigh wave solutions, distribution of data (in particular, the availability of regional data), possible uncertainties, and inconsistent arrivals were taken into account. We note that many of the mechanisms for this region by Franke et al. (2000) are inconsistent with CMT or waveform modeling (e.g., 1 February 1980; 10 June 1983; 8 November 1981 events); they are also discordant with regional P-wave data. It should be noted, however, that some CMT solutions (e.g., 13 September 1992) also show discrepancies with regional data. P-wave first motion solutions for smaller events $\left(m_{b}<5.2\right)$ were generally found to be unreliable or poorly constrained unless well-distributed regional first motions were available. The preferred mechanisms discussed in this paper vary greatly in quality from well constrained to those that only provide reasonable constraint on the type of faulting (Table 1). Taken together, however, these focal mechanisms provide insights on the nature of the seismotectonics in the CSB. 
Table 1. Focal mechanisms of the Chersky Seismic Belt.

\begin{tabular}{|c|c|c|c|c|c|c|c|c|c|c|c|c|c|c|c|c|c|}
\hline \multicolumn{3}{|c|}{ DATE } & \multicolumn{3}{|c|}{ ORIGIN } & \multirow{2}{*}{$\begin{array}{l}\text { LAT } \\
69.9\end{array}$} & \multirow{2}{*}{$\begin{array}{l}\text { LONG } \\
129.9\end{array}$} & \multirow{2}{*}{$\begin{array}{l}\text { MAG } \\
6.8\end{array}$} & \multicolumn{3}{|c|}{ PLANE 1} & \multicolumn{3}{|c|}{ PLANE 2} & \multirow{2}{*}{$\begin{array}{l}\text { METH } \\
\text { PB }\end{array}$} & \multirow{2}{*}{$\begin{array}{l}\text { REF } \\
\text { IMV }\end{array}$} & \multirow{2}{*}{$\frac{\mathrm{Q}}{2}$} \\
\hline 14 & Nov & 1927 & 00 & 12 & 05 & & & & 025 & 65 & -130 & 268 & 46 & -35 & & & \\
\hline 12 & Feb & 1951 & 17 & 22 & 06 & 65.0 & 137.0 & 6.4 & 143 & 64 & 105 & 292 & 29 & 62 & PB & MIS & 3 \\
\hline 14 & Apr & 1951 & 13 & 32 & 59 & 61.3 & 137.4 & 6.0 & 192 & 50 & 53 & 61 & 52 & 124 & SYN & GAO & 1 \\
\hline 30 & Oct & 1959 & 04 & 00 & 32 & 65.9 & 137.0 & 5.2 & 330 & 50 & 90 & 150 & 40 & 90 & PB & $\mathrm{COO}$ & 2 \\
\hline 3 & Dec & 1960 & 20 & 20 & 59 & 76.6 & 131.2 & 5.1 & 167 & 72 & -90 & 347 & 18 & -90 & PB & $\mathrm{COO}$ & 2 \\
\hline 19 & Apr & 1962 & 23 & 16 & 05 & 69.5 & 138.5 & 6.0 & 120 & 40 & 100 & 287 & 51 & 82 & SYN & RGL & 1 \\
\hline 20 & May & 1963 & 17 & 01 & 35 & 72.2 & 126.3 & 5.0 & 260 & 75 & -21 & 356 & 70 & -164 & SYN & RGL & 1 \\
\hline 21 & Jul & 1964 & 09 & 56 & 17 & 72.2 & 130.0 & 5.4 & 339 & 50 & -70 & 130 & 45 & -112 & SYN & RGL & 1 \\
\hline 9 & Sep & 1968 & 02 & 20 & 59 & 66.2 & 142.1 & 5.0 & 250 & 81 & 25 & 156 & 65 & 170 & SYN & RGL & 1 \\
\hline 7 & Apr & 1969 & 20 & 26 & 31 & 76.5 & 130.8 & 5.4 & 314 & 48 & -106 & 157 & 45 & -73 & PSH & JEM & 1 \\
\hline 5 & Jun & 1970 & 10 & 31 & 54 & 63.3 & 146.2 & 5.4 & 212 & 79 & 168 & 304 & 78 & 11 & SYN & RGL & 1 \\
\hline 18 & May & 1971 & 22 & 44 & 42 & 64.0 & 146.1 & 6.4 & 305 & 82 & 6 & 214 & 84 & 172 & SYN & RGL & 1 \\
\hline 30 & Sep & 1971 & 21 & 31 & 26 & 61.6 & 140.4 & 5.5 & 241 & 89 & -179 & 150 & 89 & -1 & SYN & RGL & 1 \\
\hline 13 & Jan & 1972 & 17 & 24 & 20 & 61.9 & 147.0 & 5.3 & 260 & 72 & -24 & 358 & 68 & -159 & PLR & $\mathrm{KOZ}$ & 1 \\
\hline 19 & Jun & 1974 & 03 & 09 & 37 & 63.2 & 151.0 & 4.9 & 146 & 77 & 0 & 236 & 90 & 167 & PL & $\mathrm{KOZ}$ & 1 \\
\hline 12 & Aug & 1975 & 15 & 00 & 00 & 70.8 & 127.1 & 5.1 & 330 & 65 & 22 & 230 & 71 & 153 & SYN & FUJ & 1 \\
\hline 4 & Nov & 1975 & 12 & 41 & 05 & 59.8 & 160.3 & 4.7 & 143 & 33 & 90 & 323 & 57 & 90 & PL & $\mathrm{KOZ}$ & 1 \\
\hline 21 & Jan & 1976 & 06 & 01 & 49 & 67.7 & 140.2 & 5.0 & 095 & 60 & 12 & 359 & 80 & 149 & SYN & RGL & 1 \\
\hline 24 & Jul & 1976 & 18 & 47 & 57 & 71.1 & 136.5 & & 177 & 65 & -113 & 042 & 33 & -50 & PL & NEW & 1 \\
\hline 23 & Apr & 1977 & 14 & 49 & 09 & 75.2 & 134.5 & 5.0 & 030 & 45 & -90 & 210 & 45 & -90 & SYN & OLS & 1 \\
\hline 18 & Nov & 1977 & 21 & 55 & 36 & 60.1 & 143.4 & 4.5 & 107 & 21 & -11 & 207 & 86 & -110 & PL & IMA & 2 \\
\hline 5 & Jun & 1978 & 07 & 05 & 52 & 60.0 & 160.4 & 5.1 & 006 & 26 & 119 & 165 & 67 & 77 & $\mathrm{CMT}$ & HRV & 1 \\
\hline 19 & Aug & 1979 & 07 & 10 & 06 & 61.3 & 159.1 & 5.3 & 185 & 70 & -166 & 090 & 77 & -21 & CMT & HRV & 1 \\
\hline 7 & Oct & 1979 & 01 & 29 & 26 & 65.0 & 144.0 & 4.8 & 320 & 45 & 115 & 107 & 50 & 67 & PL & NEW & 2 \\
\hline 1 & $\mathrm{Feb}$ & 1980 & 17 & 30 & 25 & 73.1 & 122.6 & 5.4 & 315 & 55 & -78 & 114 & 36 & -107 & $\mathrm{CMT}$ & HRV & 1 \\
\hline 22 & May & 1981 & 04 & 59 & 21 & 61.1 & 156.7 & 5.1 & 278 & 45 & 71 & 124 & 48 & 108 & SYN & MCM & 1 \\
\hline 29 & Aug & 1981 & 22 & 23 & 52 & 65.5 & 136.4 & 4.7 & 142 & 57 & 175 & 235 & 85 & 33 & PL & IMA & 3 \\
\hline 8 & Nov & 1981 & 21 & 56 & 09 & 61.8 & 153.7 & 5.4 & 127 & 36 & 20 & 020 & 78 & 125 & $\mathrm{CMT}$ & HRV & 1 \\
\hline 3 & Sep & 1982 & 07 & 29 & 26 & 66.9 & 133.3 & 4.5 & 117 & 72 & -169 & 024 & 80 & -18 & PL & IMA & 2 \\
\hline 25 & Mar & 1983 & 10 & 36 & 55 & 63.6 & 149.9 & 4.7 & 108 & 56 & 112 & 252 & 50 & 108 & PL & NEW & 1 \\
\hline 10 & Jun & 1983 & 02 & 13 & 23 & 75.4 & 121.9 & 5.5 & 160 & 74 & -125 & 049 & 38 & -27 & SYN & RGL & 1 \\
\hline 2 & Aug & 1984 & 21 & 25 & 39 & 60.9 & 144.6 & 4.9 & 332 & 90 & 180 & 242 & 90 & 0 & PL & RGL & 2 \\
\hline 12 & Aug & 1984 & 15 & 28 & 03 & 74.8 & 136.6 & 5.0 & 000 & 55 & -59 & 134 & 45 & -126 & PB & FCV & 2 \\
\hline 22 & Nov & 1984 & 13 & 52 & 57 & 68.5 & 140.8 & 5.1 & 341 & 45 & 158 & 087 & 75 & 47 & CMT & HRV & 1 \\
\hline 2 & Dec & 1984 & 08 & 35 & 45 & 63.4 & 150.5 & 5.5 & 204 & 60 & 90 & 024 & 30 & 90 & PL & RGL & 2 \\
\hline 29 & Jan & 1985 & 00 & 36 & 06 & 64.2 & 145.8 & 4.5 & 025 & 45 & 90 & 205 & 45 & 90 & PL & RGL & 2 \\
\hline 2 & Jun & 1985 & 04 & 08 & 09 & 64.9 & 144.1 & 4.3 & 150 & 60 & 18 & 051 & 74 & 149 & PL & RGL & 2 \\
\hline 24 & Jun & 1985 & 03 & 54 & 35 & 65.3 & 144.7 & 4.6 & 284 & 70 & 43 & 176 & 50 & 154 & PL & NEW & 1 \\
\hline 6 & Apr & 1986 & 01 & 27 & 21 & 70.8 & 130.3 & 3.5 & 148 & 29 & -123 & 005 & 66 & -74 & PL & NEW & 2 \\
\hline 15 & Jun & 1986 & 06 & 55 & 36 & 72.8 & 126.3 & 4.7 & 013 & 50 & -38 & 130 & 60 & -134 & PL & AVE & 1 \\
\hline 18 & Dec & 1986 & 18 & 04 & 12 & 61.2 & 143.7 & 4.6 & 117 & 72 & -27 & 216 & 64 & -160 & PL & RGL & 2 \\
\hline 11 & $\mathrm{Feb}$ & 1987 & 00 & 58 & 21 & 62.9 & 156.9 & 4.9 & 094 & 87 & 90 & 274 & 03 & 90 & PL & RGL & 1 \\
\hline 11 & Feb & 1987 & 01 & 09 & 52 & 62.8 & 156.8 & & 081 & 76 & 48 & 346 & 32 & 173 & PL & KOV & 2 \\
\hline 11 & Feb & 1987 & 06 & 19 & 16 & 62.9 & 156.8 & 4.2 & 106 & 31 & 51 & 329 & 66 & 110 & PL & GUB & 3 \\
\hline 11 & Feb & 1987 & 07 & 28 & 18 & 62.8 & 156.9 & & 033 & 55 & 44 & 274 & 55 & 136 & PL & KOV & 1 \\
\hline 11 & $\mathrm{Feb}$ & 1987 & 07 & 29 & 00 & 62.9 & 156.9 & & 074 & 85 & 94 & 207 & 06 & 44 & PL & GUB & 3 \\
\hline 22 & Mar & 1987 & 01 & 14 & 10 & 71.5 & 128.9 & & 105 & 75 & 130 & 212 & 42 & 22 & PL & IMV & 2 \\
\hline 30 & Jul & 1987 & 18 & 51 & 28 & 72.3 & 128.1 & & 035 & 20 & -170 & 295 & 86 & -70 & PL & IMV & 2 \\
\hline 22 & Sep & 1987 & 22 & 05 & 18 & 76.4 & 134.2 & 5.5 & 006 & 41 & -69 & 159 & 52 & -107 & $\mathrm{CMT}$ & HRV & 1 \\
\hline 25 & Nov & 1987 & 17 & 28 & 01 & 73.8 & 118.9 & 5.1 & 155 & 62 & -47 & 272 & 50 & -142 & PB & FCV & 2 \\
\hline 1 & Jan & 1988 & 14 & 36 & 10 & 74.6 & 130.8 & 5.1 & 175 & 29 & -122 & 031 & 65 & -73 & CMT & HRV & 1 \\
\hline 21 & Mar & 1988 & 23 & 31 & 25 & 77.6 & 125.5 & 6.2 & 178 & 34 & -73 & 339 & 58 & -101 & CMT & HRV & 1 \\
\hline 14 & May & 1988 & 13 & 25 & 50 & 71.8 & 130.3 & & 065 & 75 & -40 & 167 & 51 & -160 & PL & IMV & 2 \\
\hline 9 & Apr & 1989 & 04 & 16 & 23 & 59.8 & 145.1 & 4.8 & 349 & 32 & 173 & 085 & 86 & 58 & PSL & GUN & 1 \\
\hline 5 & Aug & 1989 & 06 & 55 & 50 & 75.4 & 133.4 & 5.3 & 348 & 40 & -93 & 172 & 50 & -87 & $\mathrm{CMT}$ & HRV & 1 \\
\hline 2 & Nov & 1989 & 04 & 40 & 42 & 71.1 & 129.5 & & 035 & 65 & -60 & 161 & 38 & -136 & PL & IMV & 2 \\
\hline
\end{tabular}


Table 1. Continued.

\begin{tabular}{llllllllllllllllll}
13 & Mar & 1990 & 00 & 32 & 59 & 73.3 & 134.8 & 5.5 & 186 & 45 & -90 & 006 & 45 & -90 & CMT & HRV & 1 \\
2 & Nov & 1990 & 21 & 54 & 03 & 64.8 & 146.6 & 4.6 & 249 & 60 & -77 & 044 & 33 & -112 & P & NEW & 2 \\
1 & Mar & 1991 & 01 & 57 & 06 & 72.2 & 126.7 & 5.2 & 154 & 70 & 108 & 290 & 27 & 49 & PBL & NEW & 1 \\
28 & Aug & 1992 & 14 & 27 & 05 & 58.9 & 149.2 & 3.8 & 162 & 74 & 67 & 040 & 28 & 145 & P & KVL & 1 \\
13 & Sep & 1992 & 21 & 42 & 56 & 62.1 & 153.8 & 4.9 & 217 & 90 & -180 & 307 & 90 & 0 & CMT & HRV & 1 \\
11 & Oct & 1992 & 21 & 40 & 09 & 62.1 & 153.6 & & 106 & 37 & -55 & 327 & 60 & -114 & P & KVL & 2 \\
5 & Oct & 1993 & 21 & 28 & 06 & 77.7 & 126.4 & 5.2 & 032 & 35 & -65 & 183 & 59 & -106 & CMT & HRV & 1 \\
22 & Jun & 1996 & 16 & 47 & 13 & 75.8 & 134.5 & 5.6 & 144 & 29 & -112 & 349 & 63 & -78 & CMT & HRV & 1 \\
7 & Jan & 1999 & 18 & 13 & 38 & 67.8 & 141.4 & 5.2 & 354 & 75 & -173 & 263 & 83 & -15 & CMT & HRV & 1 \\
7 & Jan & 2001 & 06 & 26 & 57 & 59.4 & 147.2 & 5.4 & 290 & 68 & 11 & 196 & 80 & 158 & CMT & HRV & 1 \\
7 & Dec & 2003 & 09 & 16 & 20 & 74.1 & 134.8 & 5.1 & 036 & 34 & -39 & 160 & 69 & -118 & CMT & HRV & 1 \\
25 & Jan & 2005 & 22 & 21 & 57 & 69.7 & 138.9 & 5.1 & 251 & 64 & 4 & 159 & 87 & 154 & CMT & HRV & 1 \\
19 & Oct & 2006 & 07 & 15 & 37 & 64.1 & 148.9 & 5.2 & 031 & 54 & 170 & 128 & 82 & 36 & CMT & HRV & 1 \\
22 & Jun & 2008 & 22 & 56 & 50 & 67.7 & 141.3 & 6.1 & 096 & 64 & 41 & 345 & 54 & 147 & CMT & HRV & 1 \\
COMPOSITE 1 & $1985-1988$ & 73.0 & 124.1 & & 013 & 59 & -38 & 130 & 60 & -134 & PL & AVE & 1 \\
COMPOSITE 2 & $1985-1988$ & 72.6 & 126.0 & & 324 & 58 & -87 & 138 & 32 & -95 & PL & AVE & 1 \\
COMPOSITE 3 & $1985-1988$ & 71.7 & 130.6 & & 345 & 30 & 109 & 143 & 63 & 80 & PL & AVE & 1 \\
\hline
\end{tabular}

NOTES: Date and origin time given in UTC from various sources. Latitude in degrees north, longitude in degrees east. Magnitude is $M_{w}$ where available, ISC $\mathrm{M}_{S}$ or $m_{b}$ otherwise. Nodal planes are given by strike dip and rake. Method(s) used (METH), CMT - Centroid Moment Tensor, P - P-waves, at least partially reread, PB - bulletin reported P-wave, PBL - P-waves, both bulletin and regional, PL local and regional P-waves, PSH - P- and SH-waves, PSL - regional P- and S-waves, SYN - synthetic seismograms. References (REF): AVE - Avetisov (1991); COO - Cook (1988); FCV - Fujita et al. (1990b); FUJ - Fujita (1995); GAO - H. Gao and W. Y. Chung, personal communication, 1995; GUB - Gunbina et al. (1988); GUN - Gunbina et al. (1991); HRV - Global Centroid Moment Tensor Catalog, accessed 2008; IMA - Imaev et al. (1990); IMV - Imaev et al. (1998); JEM - Jemsek et al. (1986); KOV - Kovalev (1991); KOZ Koz'min (1984); KVL - Kovalev (1993); MCM - McMullen (1985); MIS - Misharina (1967); NEW - First reported in this paper; OLS - Olson (1990); RGL - Riegel (1994). Quality (Q): 1 - constrained to some degree; 2 - poorly constrained; 3 - unable to judge, no data available.

\subsection{Laptev segment}

The Laptev Sea shelf represents a continuation of the extensional structures of the oceanic Arctic (Gakkel) Mid-Ocean Ridge onto the northeastern Asian continent. The Laptev segment is defined by a wide (up to $600 \mathrm{~km}$ ) zone of epicenters which is composed of several bands that cross the Laptev Sea shelf between the New Siberian Islands and Taimyr Peninsula (Fig. 4). We only briefly discuss the seismicity of the Laptev segment as it has been well discussed by other authors (e.g., Jemsek et al., 1986; Fujita et al., 1990b; Avetisov, 1993, 1996, 2000)

The Main zone of seismicity, with larger earthquakes ( $M \sim 5.5-7.0$ ), extends southeast from the termination of the Arctic (Gakkel) Mid-Ocean Ridge to Yana Bay along the eastern side of the Laptev Sea and is suggested to mark the boundary between the Eurasian and North American plates (Fujita et al., 1990b). Most of the earthquakes of this zone are clustered along grabens (e.g., Bel'kov-Svyatoi Nos rift) identified from gravity and seismic reflection data (e.g., Kim, 1986; Gramberg et al., 1990; Avetisov, 1993, 1996; Drachev et al., 1998; Piskarev et al., 1999).

The rest of the shelf has more diffuse seismicity. The Ust' Lena rift, once thought to be the primary continuation of the Arctic Mid-Ocean Ridge, has considerably less seismicity associated with it than the grabens to the east and is likely an older, abandoned, rift segment. Some seismicity may be associated with the Omoloi rift of Kim (1986).

All earthquakes on the shelf have extensional or transtensional mechanisms (Chapman and Solomon, 1976; Jemsek et al., 1986; Fujita et al., 1990a, 1990b; Avetisov, 1993, 1996), with one or both nodal planes parallel to the strike of the grabens. Focal depths generally increase from 10 to $20 \mathrm{~km}$ towards the south (Jemsek et al., 1986). These data indicate that the extensional tectonics associated with the Arctic MidOcean Ridge today extend beyond its southern terminus into the Laptev Sea shelf and up to the coastal regions of the continent (Fujita et al., 1990b; Imaev et al., 1998).

In conjunction with the Coastal zone of the North Verkhoyansk segment discussed below, the two zones have been suggested to delimit a Laptev Sea block (Avetisov, 1993, 1996, 2000). However, seismicity is lacking on the western side of this proposed block, with only a few events in Taimyr and off Severnaya Zemlya (Fig. 1, inset).

\subsection{North Vekhoyansk segment}

The North Verkhoyansk segment (Figs. 4 and 5) can be divided into three zones encompassing seismicity occurring along the southwestern coast of the Laptev Sea and in the 


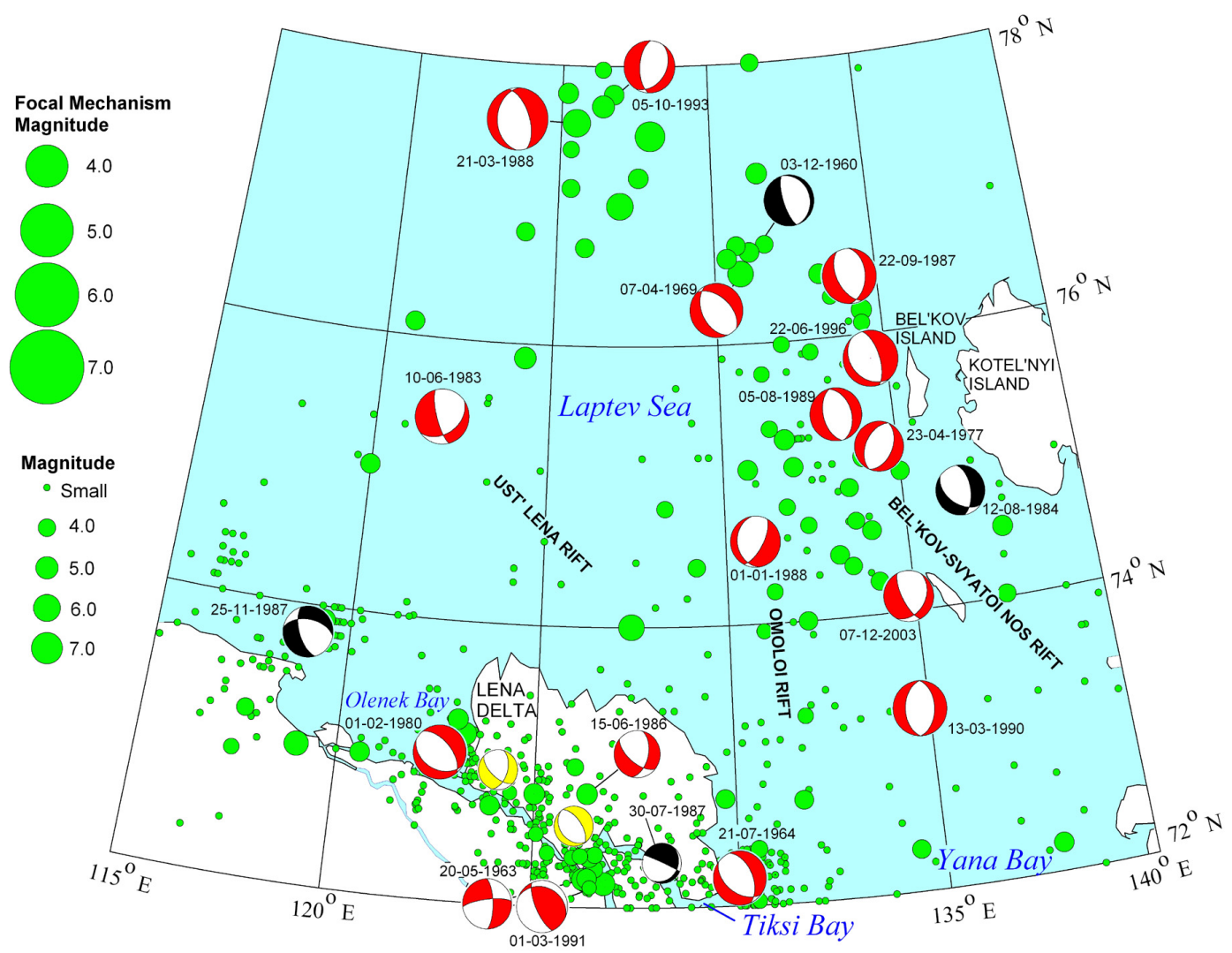

Fig. 4. Seismicity and focal mechanisms of the Laptev segment of the CSB. Focal mechanisms in red are classified as reliable, those in black are less well to poorly constrained. Mechanisms in yellow are composite mechanisms from microseismicity, and ones in grey are those for which no data are available for quality judgments. Compressional quadrants of focal mechanisms are shaded and are presented as lower hemisphere projections. Dates of events give as date-month-year. Events and focal mechanisms are shown proportional in diameter to magnitude.

Lena River Delta (Coastal zone), in Buor-Khaya Bay (BuorKhaya zone), and in the northern Verkhoyansk Mountains (Kharaulakh zone). Several long, linear, trends of seismicity are noted within these zones and are presumed to represent active faults.

Focal depths are concentrated in the upper crust $(0-25 \mathrm{~km}$; Riegel, 1994; Kovachev et al., 1994) and may extend down to $35 \mathrm{~km}$ (Avetisov, 1991). Several deeper, "mantle," events (up to $82 \mathrm{~km}$ ) have been reported (Avetisov, 1991; Kovachev et al., 1994); however the high variability of the crustal structure in the region (Avetisov, 1991; Vinogradov et al., 1992) and the possibility of phase misidentification phases may affect reported focal depths. The three deepest events reported by Kovachev et al. (1994) with depths of 70-82 km are all very distant $(>150 \mathrm{~km})$ from their OBS deployment and thus located with a very narrow azimuth window. It should be noted that events with "mantle" depths have also been reported in Chukotka (Godzikovskaya and Lander, 1991) where they appear to be mislocations (Fujita et al., 2002a).

The Coastal (also Primorsky or Lena-Taimyr) seismic zone is defined by a $30-40 \mathrm{~km}$ wide band of epicenters extending from Tiksi Bay on Buor-Khaya Bay (Fig. 5), across the Lena River Delta, to Olenek Bay of the Laptev Sea (Fig. 4) and on to Taimyr Peninsula. Events in this zone have ranged up to magnitude 5.4 .

West of the Lena River Delta, the events of this zone are dominantly extensional with north-northeast striking tension (Avetisov, 1993; Riegel, 1994; Imaev et al., 1998); that is, perpendicular to the local coastline. This is best demonstrated by 1 February 1980 event located in eastern Olenek Bay (Figs. 4 and 6). The plunge of the intermediate stress-axis varies among solutions, but the orientation of the tension-axis is consistent (Cook, 1988; Dziewonski et al., 1988; Olson, 1990; Riegel, 1994). Fujita et al. (1990b) suggested that this part of the Coastal zone may be due to detachment faulting at the edge of a complex extensional system similar to the Basin and Range of the western United States.

In the channel of the Lena River, however, a magnitude 5.3 event on 20 May 1963, appears to be almost pure strike-slip with northeast striking compression (Figs. 4 and 7). This event does not model as well as others using short-period records. A smaller event on 15 June 1986, is even less well constrained, although the available data could be interpreted 


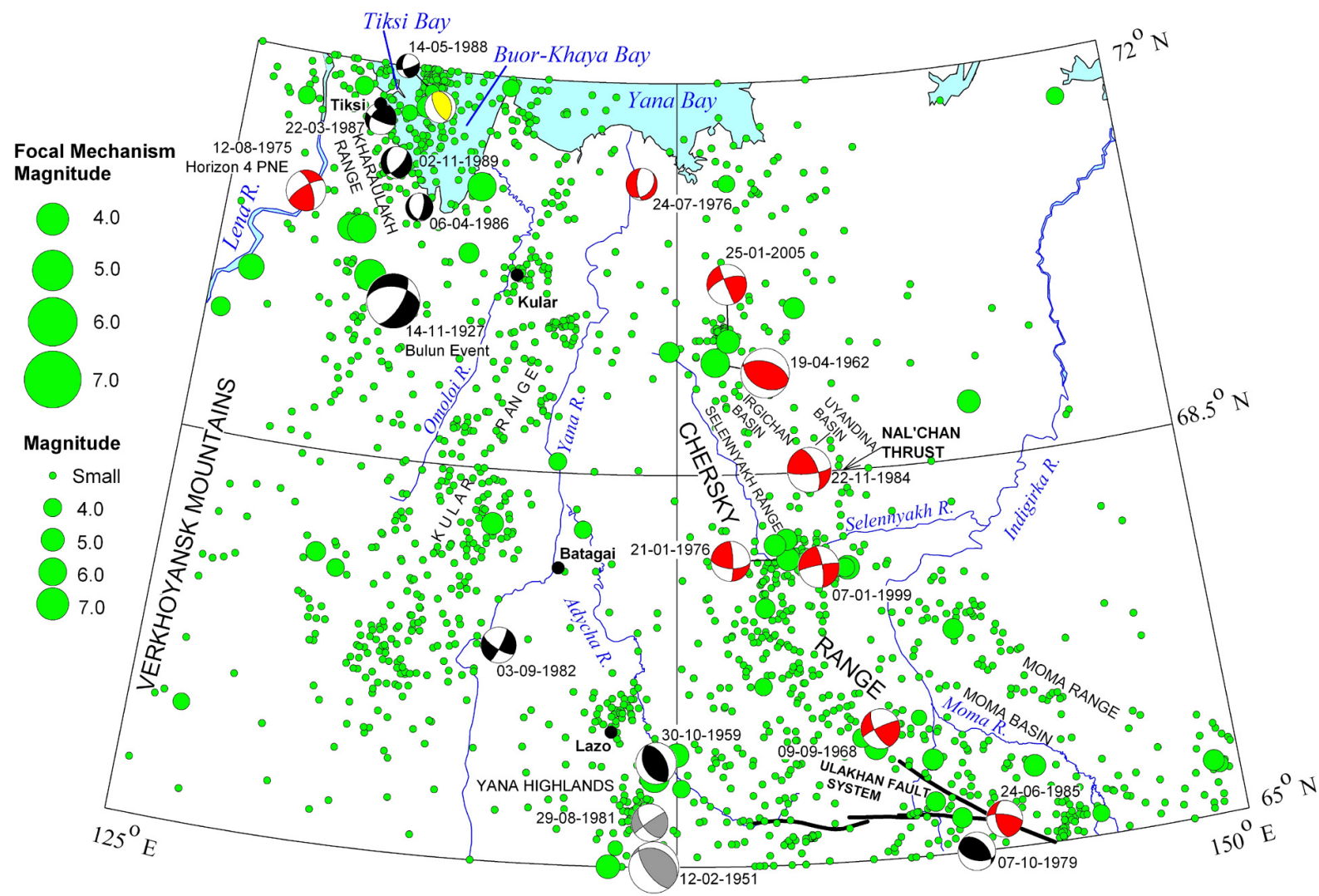

Fig. 5. Seismicity and focal mechanisms of the North Verkhoyansk segment and the Northwest Chersky seismic zone of the Chersky segment of the CSB. Conventions as in Fig. 4.

similar to the 1963 event. If these latter mechanisms are reliable, there is a transition from northeast directed extension to compression as one moves eastward along the Coastal zone in the Lena delta region. This may reflect interaction between the rift and the solid crust of the Siberian craton or a transfer fault that offsets the locus of extension.

The Buor-Khaya seismic zone is primarily defined by a north-south trend of epicenters roughly along the center of Buor-Khaya Bay (Fig. 5). This zone appears to link with the Main band of the Laptev Sea to the north and extends to the mouth of the Omoloi River in the south. The seismicity of this area has been studied in detail using temporary local networks deployed by PGO "Sevmorgeologiya" in 1972-1976 (Avetisov, 1975) and 1985-1988 (Avetisov, 1991), and ocean bottom seismometers deployed by the P. P. Shirshov Institute of Oceanology in 1989 (Kovachev et al., 1994). In addition, several stations of the Yakut EMSD have been deployed in this area.

The largest earthquake $\left(m_{b} 5.4\right)$ in this area occurred on 21 July 1964. The focal mechanism based on reread teleseismic first motions, synthetic seismograms, and the Rayleigh wave radiation pattern is an almost pure normal fault with extension perpendicular to the strike of the zone (Figs. 4 and 8; Cook, 1988; Olson, 1990; Riegel, 1994). The more trans- pressional mechanism proposed by Koz'min (1984) is inconsistent with observed teleseismic waveforms. Normal faults are mapped along the coast of Buor-Khaya Bay (Imaev et al., 1998) and many of them show listric characteristics.

A composite mechanism, using microseismicity just to the south of the 1964 event constructed from local station data in 1985-1988, however, indicates a diametrically opposite mechanism (Fig. 5), almost pure compression (Avetisov, 1991). This discrepancy is difficult to explain.

There is limited first motion data available for 6 April 1986 event $\left(m_{b} \sim 3.5\right.$; Fig. 5$)$ at the southern end of Buor Khaya Bay and 24 July 1976 event $\left(m_{b} 4.3\right.$; Fig. 5$)$ in the Yana River delta. Both are consistent with either east-west extension, similar to the 1964 event in Buor-Khaya Bay, or transpression with north-northeast striking compression.

The Kharaulakh seismic zone is located within the northsouth striking Kharaulakh Range (Fig. 5). It has experienced very strong historic earthquakes and appears to represent a transition zone between the extensional seismicity and structures of the Laptev Sea and the compressional features of the Chersky Range. The strongest events in historical times, the Bulun sequence, occurred in 1927-1928 and included five large events with estimated magnitudes ranging from 5.8 to 6.8. The events occurred $120-160 \mathrm{~km}$ south of Tiksi (Fig. 5) 


\section{1}

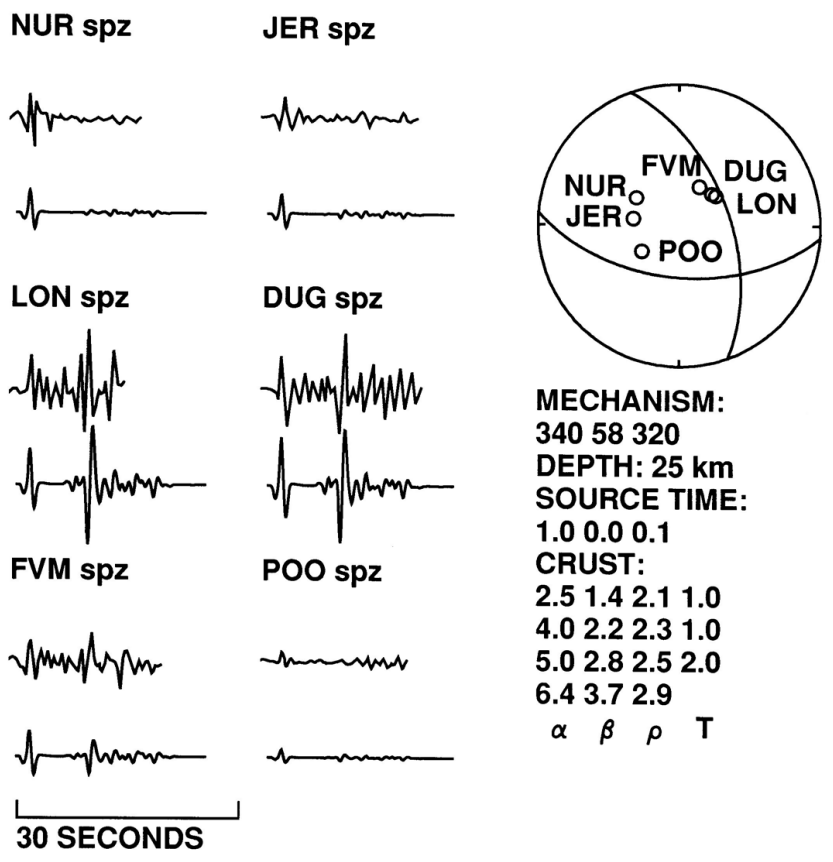

Fig. 6. Synthetic seismograms and focal mechanism for 1 February 1980 event in the Coastal seismic zone of the North Verkhoyansk segment. spz denotes short period vertical record, lpz denotes long period vertical record. Observed (top) and synthetic (bottom) seismograms computed using the method of Kroeger (1987) are shown for each station. Best fit focal mechanisms and first motions at modeled stations are shown (open circle, dilatation; closed circle, compression; triangles shown when first motion was not picked or was nodal). Also shown are parameters of best fit mechanism (strike, dip, slip of nodal plane), focal depth in $\mathrm{km}$, trapezoidal source time function in seconds and crustal structure used $(\alpha-\mathrm{P}$-wave velocity in $\mathrm{km} / \mathrm{s}, \beta-\mathrm{S}$-wave velocity in $\mathrm{km} / \mathrm{s}, \rho-$ density in $\mathrm{gm} / \mathrm{cm}^{3}$, and $\mathrm{T}$ - layer thickness in km). Scale shows time (After Riegel, 1994).

and, based on the fact that the $\mathrm{S}-\mathrm{P}$ times recorded at Irkutsk varied by only $1.6 \mathrm{~s}$, they occurred in essentially the same place. According to the newspaper Autonomous Yakutia, the Bulun earthquake of 14 November 1927, was strongly felt in the Bulun district (lower Lena region), including Kyusyur. Four shocks occurred that day, followed by aftershocks the next day, and landslides were reported in the Kharaulakh Range (Kochetkov, 1966).

Instrumental study of the region during 1985-1998, including short term temporary deployments by PGO "Sevmorgelogiya", confirmed that the Kharaulakh Range is seismically active throughout its length. Seismicity can be traced by a string of weak earthquakes $\left(m_{b} \sim 2.5-4\right)$ from the epicenters of the Bulun events in the south to Tiksi in the north. A moderate shock $\left(m_{b} \sim 4.2\right)$ occurred within the presumed epicentral region of the Bulun events in 1986.

\section{0}

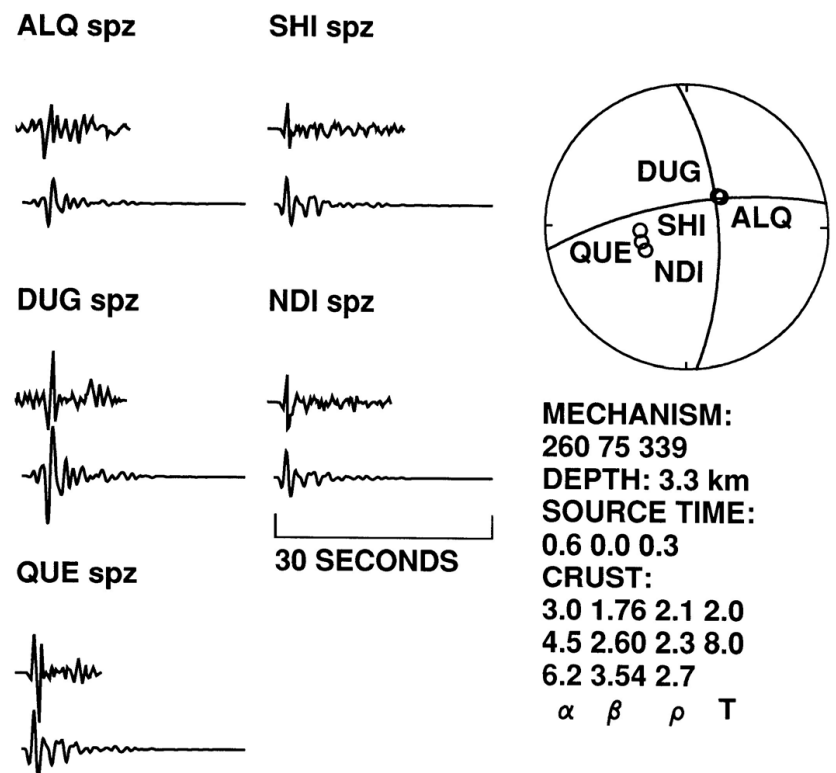

Fig. 7. Synthetic seismograms and focal mechanism of 20 May 1963 event in the Coastal seismic zone of the North Verkhoyansk segment of the CSB. Conventions as in Fig. 6 (after Riegel, 1994).

\section{1}

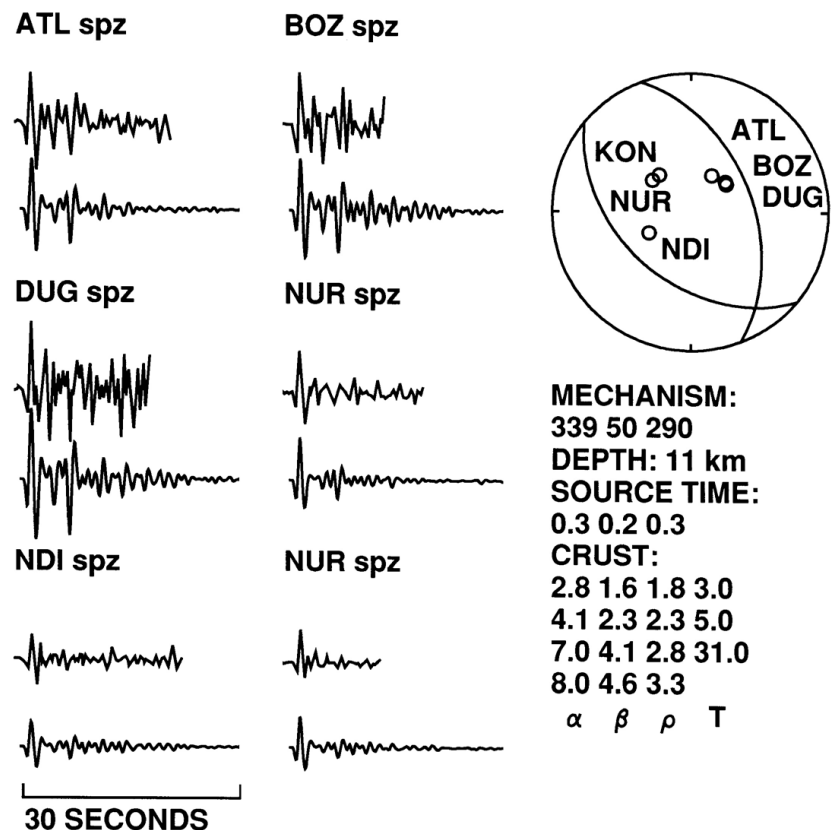

Fig. 8. Synthetic seismograms and focal mechanism of 21 July 1964 event in the Buor-Khaya seismic zone of the North Verkhoyansk segment of the CSB. Conventions as in Fig. 6 (after Riegel, 1994). 
A number of focal mechanisms for small events of the area, as well as for the 1927 Bulun event calculated by S. U. Kukhmazov (reported in Imaev et al., 1998), suggest a mix of compressional and extensional events; however, all the mechanisms are extremely poorly constrained and should be viewed as speculative at best.

A number of seismically generated landslides and ground fractures are observed in the epicentral region of the Bulun earthquakes (Fig. 5; Imaev et al., 1990, 1995, 1998, 2000). Some of these may be a result of the 1927-1928 sequence (Imaev et al., 1990), although most are likely older - perhaps several hundred years. In the Arctic, it is known that such traces of strong events are preserved in the relief over a long time, possibly thousands of years (Khromovskikh et al., 1979). These seismically generated features indicate that this region is capable of experiencing earthquakes with magnitudes up to about 7.5. Based on river offsets, the sense of motion on the main fault in the Bulun area is right-lateral strike-slip (Imaev et al., 1990, 1998).

A magnitude 5.l event on the Lena River (Fig. 5) on $12 \mathrm{Au}-$ gust 1975, was long listed both in Russian and international catalogs as a natural earthquake. However, this event, while possibly releasing tectonic stresses, was the detonation of the peaceful nuclear explosion "Horizon-4" (Fujita, 1995) for crustal refraction studies (Vinnik and Yegorkin, 1982). Synthetic seismogram modeling indicates a focal depth of $<0.5 \mathrm{~km}$.

\subsection{Chersky Range segment}

The distribution of epicenters in the Chersky Range segment is inhomogeneous and irregularly distributed (Figs. 2, 5, and 9). In general, the seismicity forms a wide, diffuse band several hundred $\mathrm{km}$ wide that crosses northeast Russia from the southern end of Buor-Khaya Bay (Laptev Sea) to the Sea of Okhotsk and continues to the Kamchatka Peninsula. The seismicity of the region is dominated by numerous microearthquakes $(M \leq 3)$ along with several strong, Modified Mercalli intensity VII-IX events with $M>5$. The microseismicity is heaviest in the region northwest of Magadan, and diminishes rapidly north of the Ulakhan fault (Figs. 5 and 9). This decrease is not an artifact of station location or deployment as the operation of a station in Zyryanka (Fig. 1), north of the Ulakhan fault, from 1982 to 1990, did not alter the microseismicity distribution.

The Chersky Range segment can be divided into three seismic zones: northwest, central (Ulakhan fault), and southeast, each with widely scattered seismicity.

The Northwest Chersky seismic zone (Fig. 5) extends from the southern end of Buor-Khaya Bay to the middle Indigirka River near Ust' Nera. This area is characterized by two bands of seismicity bounding a less active region in the upper Yana River valley. The first band lies along the Kular Range on the west side of the Yana River, while the second generally follows the northern Chersky Range east of the Yana.
There is also elevated activity along the southern edge of the area in the Yana Highlands. Clusters to north of Kular and around Lazo are mining related explosions (Fujita et al., 1998; Mackey, 1999; Mackey and Fujita, 1999; Mackey et al., 2003a). The activity in the western band is more diffuse and fades into the Northern Verkhoyansk seismic zone to the northwest.

Two moderate size $(M \geq 6)$ events have occurred in this seismic zone; one in the eastern band in the northernmost Chersky Range and one in the Yana Highlands. The first occurred on 19 April 1962, $\left(M_{w}=6.0\right)$ and was located within the Cenozoic Irgichan basin. The focal mechanism is a nearly pure thrust with northeast-southwest striking compression (Figs. 5 and 10; Riegel, 1994). A $M_{w}=5.1$ transpressional event with a similar P-axis occurred just northwest of the 1962 event on 25 January 2005; this event is the northernmost clearly compressional event in the CSB.

An event south of Lazo on 12 February 1951, had a magnitude of 6.4 (Fig. 5). A generally transpressional solution (Imaev et al., 1990) is attributed to Misharina (1967); however, no solution is given in that source. A magnitude 5.2 event occurred in the same general area on 30 October 1959. The epicentral region of these events continues to have elevated activity (Mackey, 1999). The focal mechanism of the 1959 event is poorly constrained, but available first motion data indicate that it has a significant thrust component. Earlier solutions (c.f., Lazareva and Misharina, 1965; Misharina, 1967) have some reporting inconsistencies and their quality can not be evaluated as no data are provided.

Well constrained focal mechanisms or moment tensors for five other events $(M=5.0-6.1$; 9 September $1968 ; 21$ January 1976; 22 November 1984; 7 January 1999; 22 June 2008; Fig. 5) in the eastern band indicate thrusting to right-lateral transpression with northeast striking compression (data previously presented in Riegel et al., 1993; Global CMT Catalog, 2008). The more transpressive events suggest rightlateral motion on the plane that is generally parallel to the strike of the seismicity. The 1984 event was located beneath the Uyandina basin and may have been associated with the Nal'chan thrust (Koz'min, 1987).

The Central Chersky (Ulakhan) seismic zone extends from the Indigirka River north of Ust' Nera to the SeimchanBuyunda basin at the Kolyma River (Fig. 9). This zone is the most seismically active part of the CSB. Most of the epicenters are located within the Chersky Range, with the largest events clustered along the Ulakhan and Chai-Yureya faults (Fig. 9). There is essentially no seismicity in the Moma basin (Fig. 9) to the north of the Ulakhan fault and only a few events have occurred in the Moma Range, located farther north.

Unlike in the northwestern Chersky Range, large faults are clearly identifiable in the central Chersky Range. The largest of these, the Ulakhan (meaning "great" in Yakutian), more or less forms the northern edge of the seismicity and is marked by a series of teleseisms of $M \sim 5$. The Ulakhan fault 


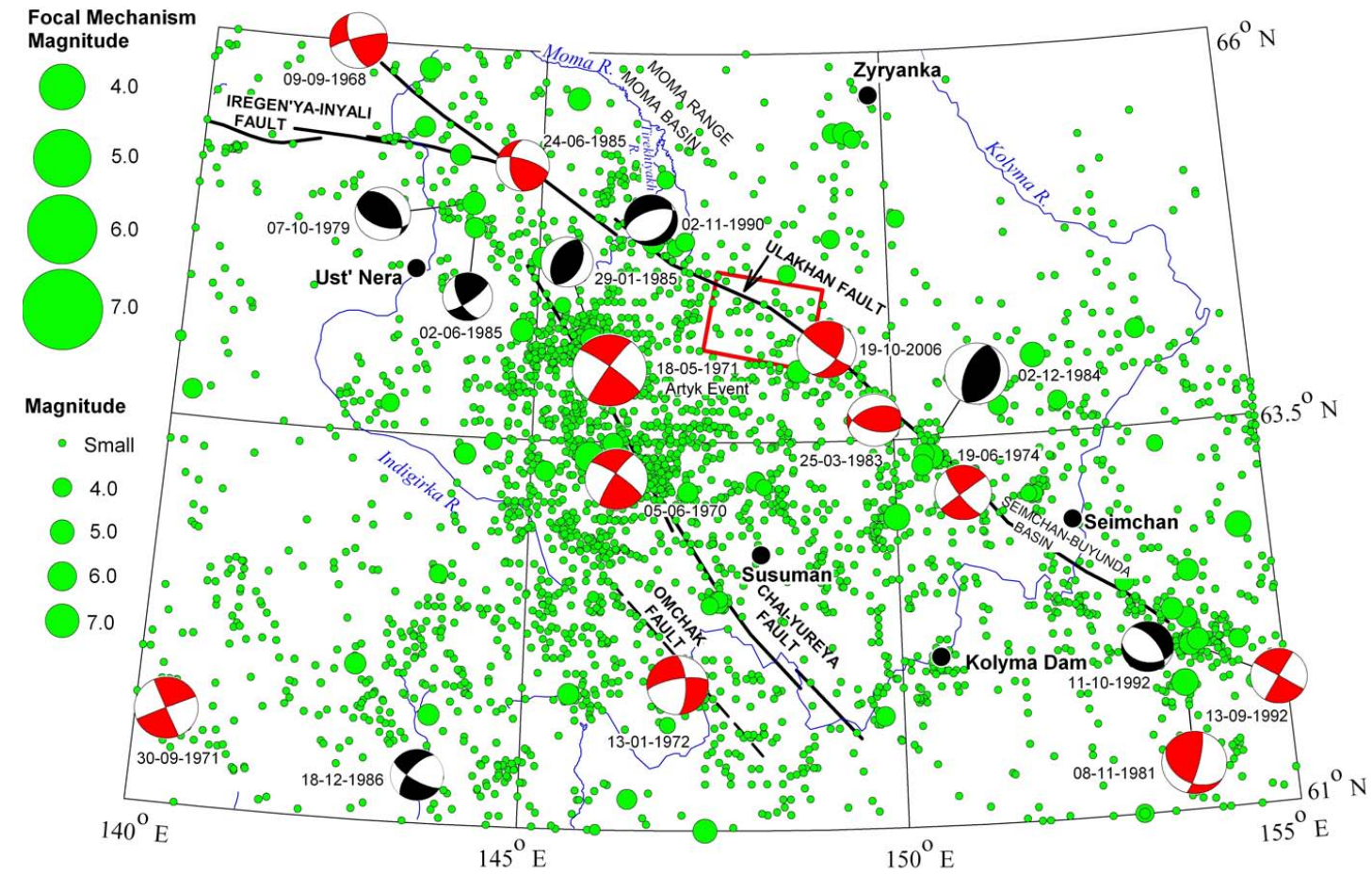

Fig. 9. Seismicity and focal mechanisms of the Central Chersky seismic zone of the Chersky segment of the CSB. Conventions as in Fig. 4. Red square shows location of Fig. 11.

is clearly seen both in satellite images (Fig. 11) and on topographic maps from the Indigirka River to the southeastern end of the Seimchan-Buyunda basin (Fig. 9). The Ulakhan dips nearly vertically where observed in the Tirekhtyakh River valley (Fig. 9; Imaev et al., 1994). Relocation of both teleseismically located $M=4-5$ events and smaller, local, events places them within 5-10 km of the Ulakhan fault.

A number of focal mechanisms have been determined for events along the Ulakhan fault (Fig. 9). One event, a $M_{w}=5.2$ event on 19 October 2006, is a clear strike slip event (Global CMT Catalog, 2008) and has one nodal plane that is essentially parallel to the Ulakhan fault. All of the other mechanisms are based on P-wave first motions, primarily from local and regional stations. Because of the size of the events there are uncertainties in determining polarities and, because of location and crustal structure uncertainties, in take-off angle for regional stations. In addition, the small number of available stations results in some planes being constrained by only one first motion. While the mechanisms, in general, are consistent with left-lateral transpression and fault-parallel extension (pull apart basins), they are highly variable and all of them must be considered poorly constrained.

As an example, Fig. 12 shows the data for 24 June 1985 event. Inclusion of regional first motion data suggests that the 24 June 1985 event $\left(m_{b} 4.6\right)$ was transpressional and similar to 9 September 1968 event with one plane parallel to the In'yali-Iregen'ya fault. However, it is possible to have a transtensional solution similar to the 19 June 1974 event;

\section{9}

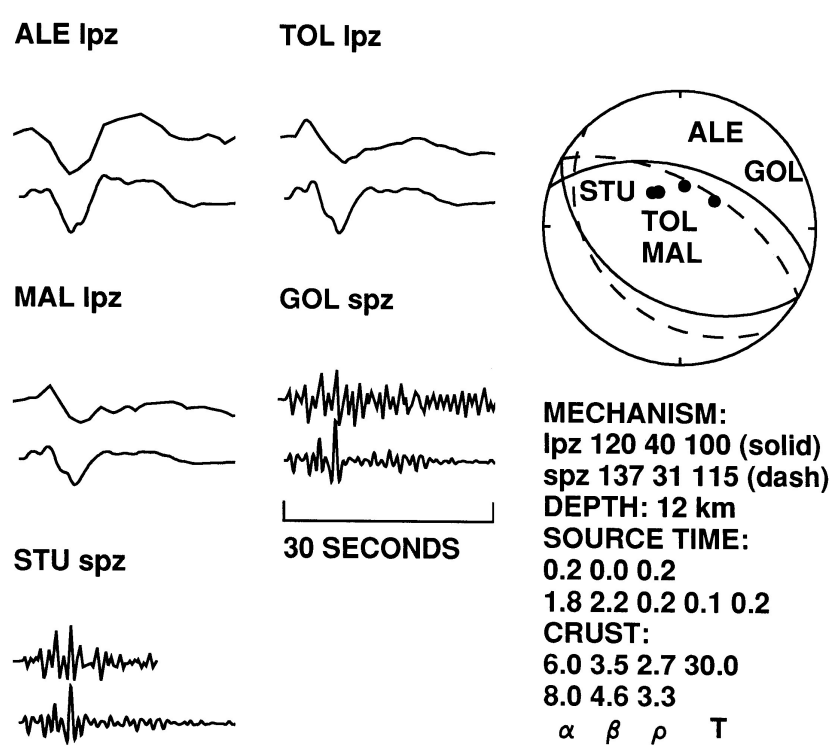

Fig. 10. Synthetic seismograms and focal mechanism of 19 April 1962 event in the Northwest Chersky seismic zone of the CSB. Two variant mechanisms are shown, the mechanism shown as the solid line is a better fit to the long-period data, the dashed line to the short period data. Conventions as in Fig. 6 (after Riegel, 1994). 


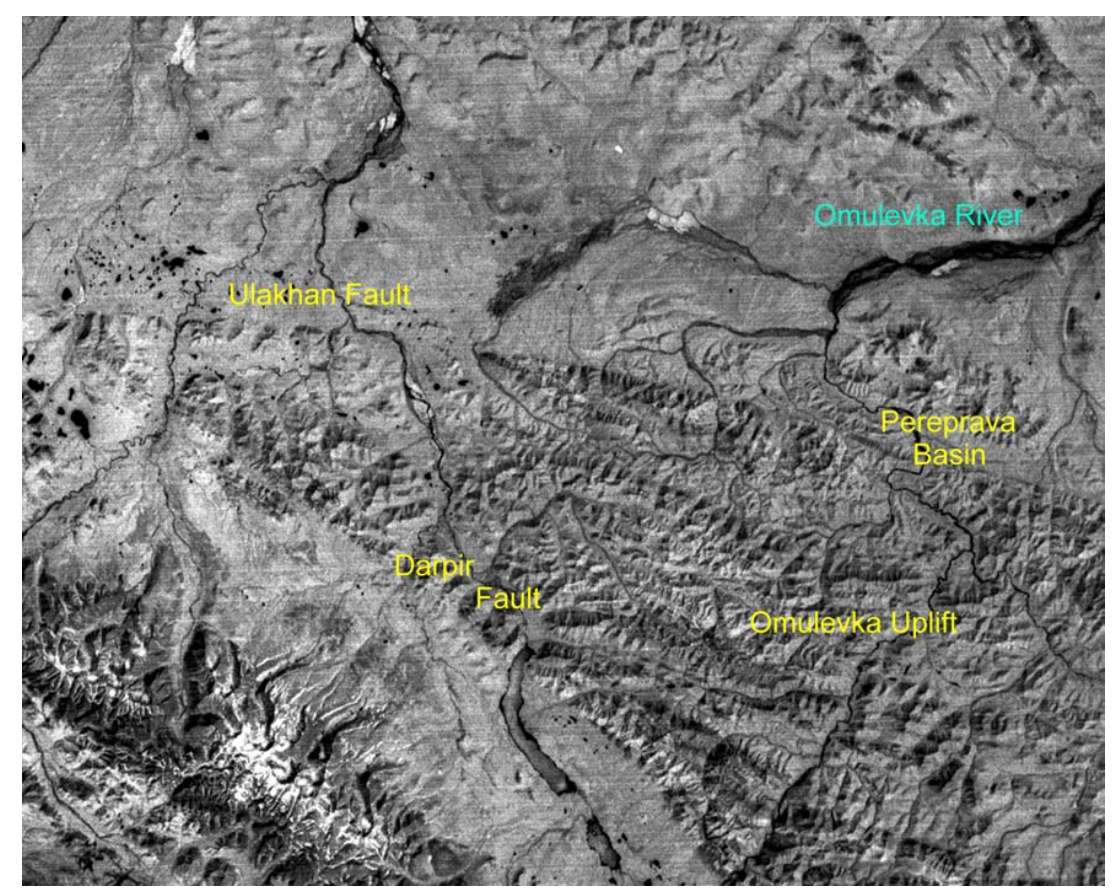

Fig. 11. Landsat image of the Ulakhan and Darpir faults in the region of the Omulevka Highlands. Left-lateral motion is apparent by river offsets along the Ulakhan Fault. See Fig. 9 for location.

the exact orientation of the planes is controlled by only a couple first motions. The 25 March 1983 event is a thrust but the orientation of the nodal planes are uncertain and the compression axis could vary from north to northeast. The 19 June 1974 event shows considerable scatter in polarities at the teleseismic stations. Although the data are generally consistent with a left-lateral strike slip mechanism (but with uncertainties in the orientations of the nodal planes of 30-40 ), a thrust mechanism with east-west striking compression is also possible. The 2 December 1984 event is also likely to be a thrust but the orientations of the nodal planes are unconstrained. The 2 November 1990 event in the Bugchan basin is a normal fault with a T-axis striking more or less southeast, consistent with a pull-apart basin. However, there is $\sim 30^{\circ}$ of play in the orientation of the nodal planes and axes.

The largest instrumental event in northeast Russia occurred on 18 May 1971 (Artyk earthquake; also referred to as the Oimyakon earthquake in earlier papers), with a magnitude of $M_{w}=6.4$ (Fujita et al., 2002b), calculated using the method of Okal and Talandier (1989). The focal mechanism for the Artyk event has been determined by a number of authors (Filson and Fraser, 1972; Chapman and Solomon, 1976; Koz'min, 1984; McMullen, 1985; Riegel et al., 1993; Balakina et al., 1993; Franke et al., 2000) with essentially the same left-lateral strike-slip solution based on first motions and waveform modeling (data previously presented in Riegel et al., 1993). The northwest $\left(305^{\circ}\right)$ striking plane is essentially parallel to the local strike of the Chai-Yureya fault $\left(314^{\circ}\right)$.

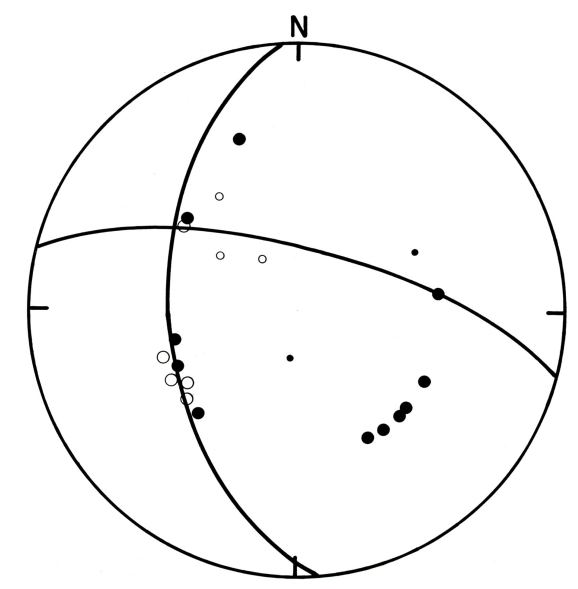

Fig. 12. P-wave first motion focal mechanism of 24 June 1985 event located on the Ulakhan or Iregen'ya-In'yali fault in the Central Chersky seismic zone of the Chersky segment of the CSB. Compressional first motions shown in black, dilitations in white. Larger dots represent regional first motions. Small dots are from seismic bulletins.

The isoseismals of the Artyk event are elliptical with the long axis oriented along the presumed fault plane (Koz'min, 1984). Massive slumps and landslides were observed in the epicentral region over an area of $18 \mathrm{~km}^{2}$. Mud flows resulted in the accumulation of sediments as thick as $5-7 \mathrm{~m}$ at the mouths of tributaries of small rivers (Koz'min, 1984; Imaev et al., 1995). 


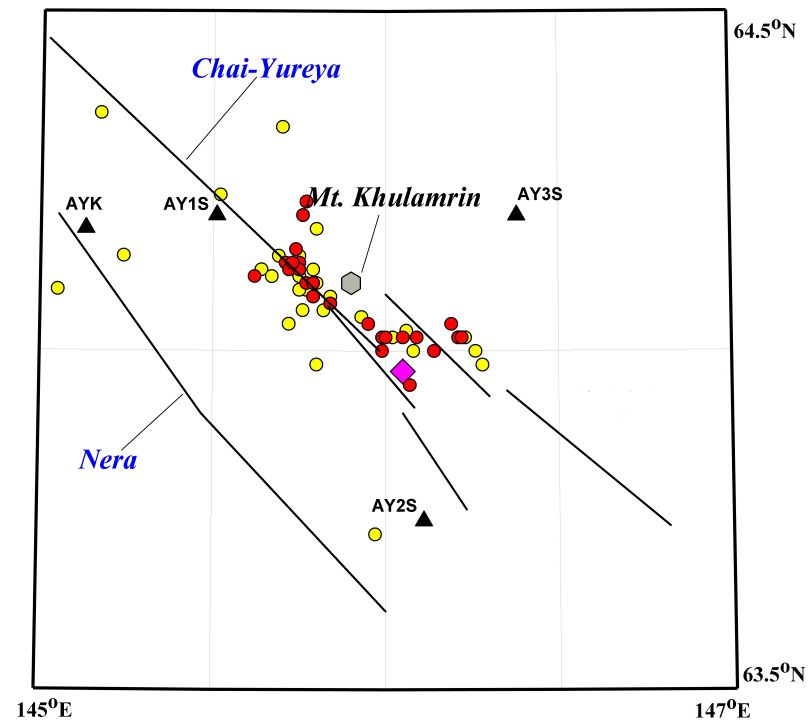

Fig. 13. Relocated aftershocks of 18 May 1971, Artyk earthquake that occurred during the second half of June 1971. Red dots denote events with better locations; yellow dots are those with greater uncertainty. Grey hexagon shows location of Mt. Khulamrin, pink diamond denotes location of 18 May mainshock, and black triangles show location of temporary stations deployed following the mainshock. Solid lines are mapped faults or lineations visible on satellite imagery, with names (after Fujita et al., 2002b).

After the main shock, over 1200 aftershocks were recorded during the remainder of 1971. Part of this aftershock sequence was recorded using four temporary stations deployed by the Yakut EMSD from June to October, 1971. Relocation of the aftershocks using a local crustal velocity $(\mathrm{Pg}=6.025 \mathrm{~km} / \mathrm{sec}, \mathrm{Sg}=3.510 \mathrm{~km} / \mathrm{sec}$; Mackey, 1999; Mackey and Fujita, 2000) demonstrates that the aftershocks primarily occurred to the east of the Upper Nera basin, along the trace of the Chai-Yureya fault, in an area more than $60 \mathrm{~km}$ long and $\sim 10 \mathrm{~km}$ wide (Fujita et al., 2002b). Events that occurred in the second half of June have the best solutions and concentrate along the Chai-Yureya fault to the north of Mt. Khulamrin, but are offset $5 \mathrm{~km}$ to the east of the ChaiYureya fault to the south of Mt. Khulamrin (Fig. 13).

Other relocated teleseismic events lie along or very close to the trace of the Chai-Yureya fault near the epicentral region of the 1971 event and to the northwest (Mackey and Fujita, 2000). The seismicity to the south of the 1971 event diminishes rapidly, although the presence of explosions in coal and placer gold mines makes it difficult to estimate the true level of natural activity.

The 5 June $1970\left(m_{b} 5.4\right)$ event occurred to the south of the Artyk event. It has essentially the same focal mechanism (Figs. 9 and 14) but is offset $50 \mathrm{~km}$ to the southwest of the Chai-Yureya fault. It is roughly in line, however, with the extrapolation of a presumed fault bounding the southwest side of the Nera basin.

\section{5}

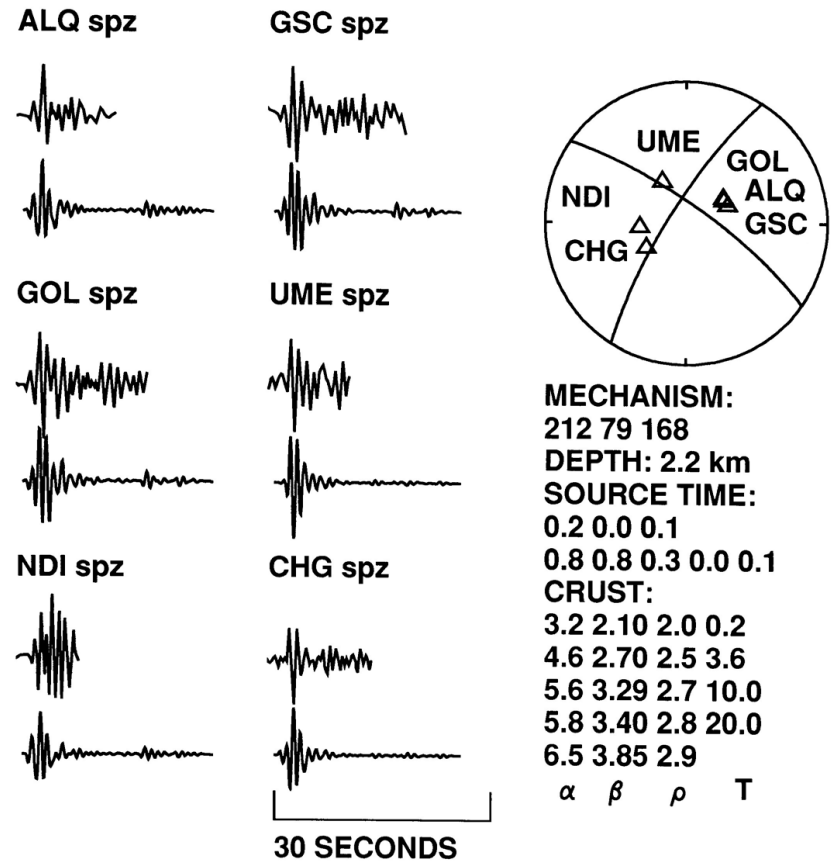

Fig. 14. Synthetic seismograms and focal mechanism of 5 June 1970 event in Central Chersky seismic zone of the Chersky segment of the CSB. Conventions as in Fig. 6 (after Riegel, 1994).

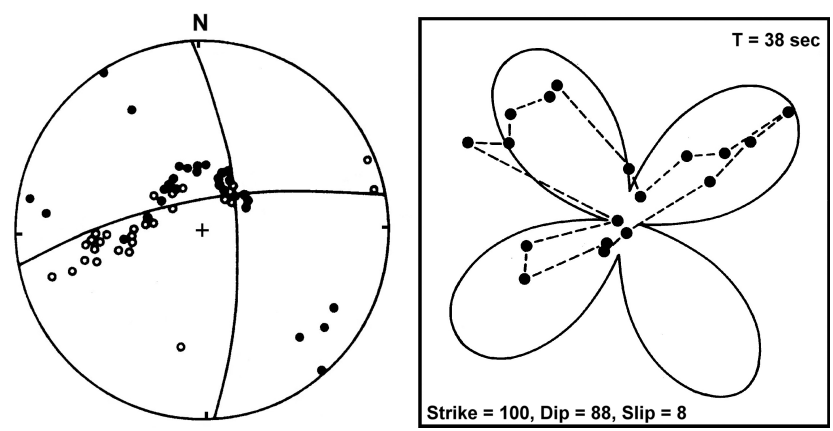

Fig. 15. Focal mechanism of 13 January 1972 event showing Pwave first motion data (left, solid dots - compression, open dots - dilatation) and Rayleigh wave radiation pattern (dots and dashed lines show calculated amplitudes, solid line denotes theoretical fit mechanism; we have no data to the southeast). While the best fit surface wave mechanism is rotated clockwise by about $20^{\circ}$, it is within the misfit error relative to the P-wave mechanism (after Koz'min, 1984 and McMullen, 1985).

The $m_{b} 5.313$ January 1972 event occurred near the Kolyma River. The event is very close to strike-slip but with more east-west oriented nodal planes than the Artyk event. It is constrained both by first motions (Koz'min, 1984) and the surface wave radiation pattern (McMullen, 1985), although it can vary from being slightly transtensional to 


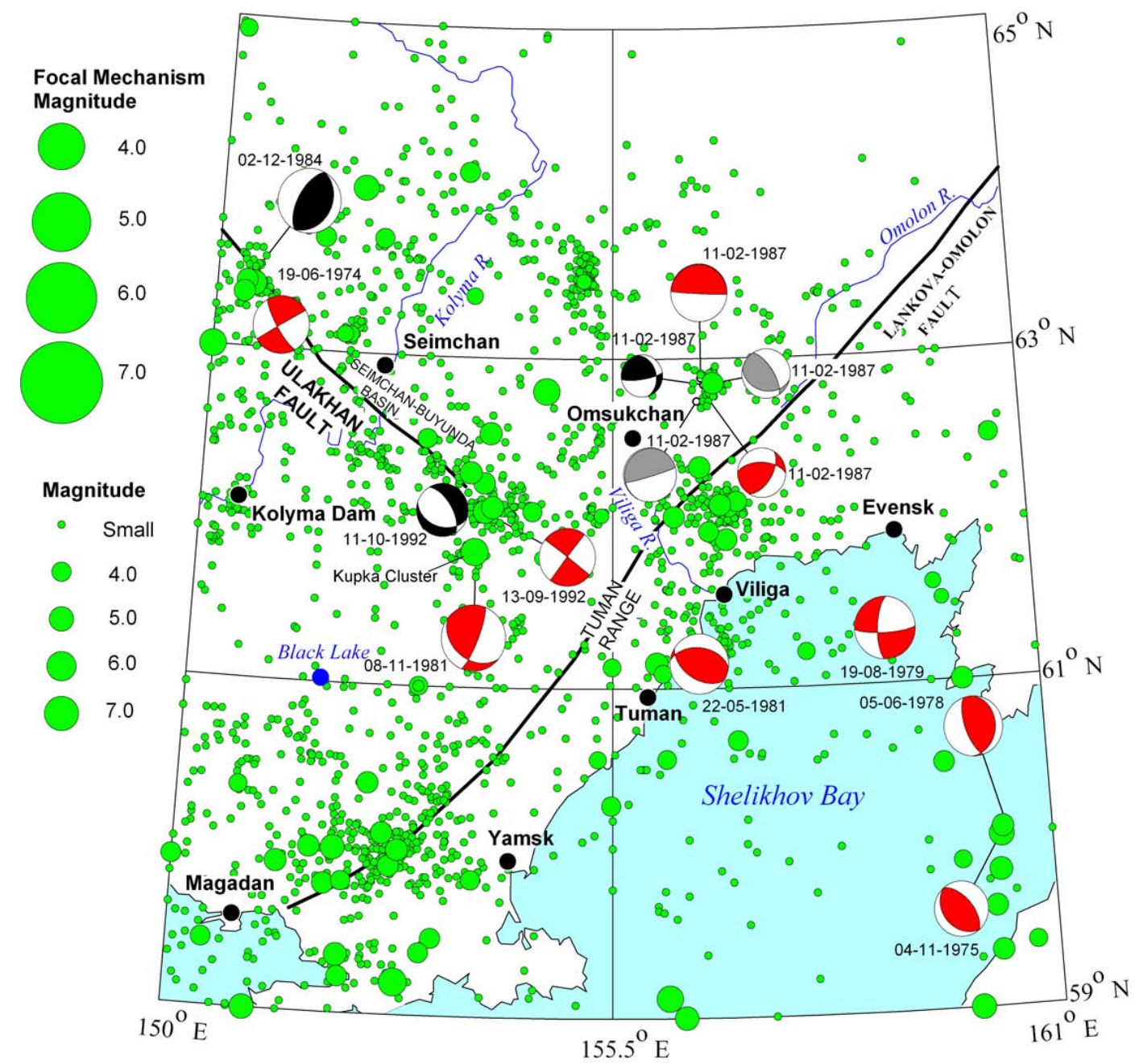

Fig. 16. Seismicity and focal mechanisms of the Southeast Chersky seismic zone of the Chersky segment and the eastern part of the Okhotsk Coastal segment of the CSB. Conventions as in Fig. 4.

slightly transpressional with uncertainty in the nodal planes of about $20^{\circ}$ (Figs. 9 and 15). The isoseismals are elongated in a northwest-southeast direction (Koz'min et al., 1976), consistent with major tectonic trends in the region and the Omchak fault of Smirnov (2000), but discordant with either of the nodal planes. The solutions by Chapman and Solomon (1976) and Savostin and Karasik (1981) are rotated about $45^{\circ}$ from the other two solutions and are concordant with the fault and isoseismals, but are discordant with regional first motion data. Initial analysis of aftershocks suggested an east-west alignment; relocation of the events, however, leaves this somewhat ambiguous. Riegel et al. (1993) suggested that the more east-west striking plane, which is sub-parallel to a lineament near the epicenter, could be the fault plane in a situation similar to the Yudoma earthquake (see Ketanda segment, below).

There are no well constrained focal mechanisms on other subsidiary faults in the zone, but one event (25 March 1983) associated with the Darpir fault (Fig. 11) is consistent with thrusting with a small right-lateral strike-slip component (Imaev et al., 1990).

The Southeast Chersky Range seismic zone (Fig. 16) extends from the Seimchan-Buyunda basin to Shelikhov Bay of the Sea of Okhotsk. The seismicity of this zone merges with the Okhotsk Sea segment on the south and also continues across the Sea of Okhotsk to Kamchatka (Savostin and Karasik, 1981; Savostin et al., 1983; Parfenov et al., 1988; Fujita et al., 1990a).

To the southeast of the Seimchan-Buyunda basin, a number of events form a north-south trend known as the Kupka cluster. $M=5.0-5.4$ earthquakes, and aftershocks, occurred here in 1979 and 1981 (Vladimirova et al., 1984). The moment tensor for the $M_{w}=5.4$ event of 8 November 1981, is thrust faulting along a north-northeast striking plane (Fig. 16; Global CMT Catalog, 2008); the isoseismals also are slightly elongate with a northeast strike (Vladimirova et al., 1984). 


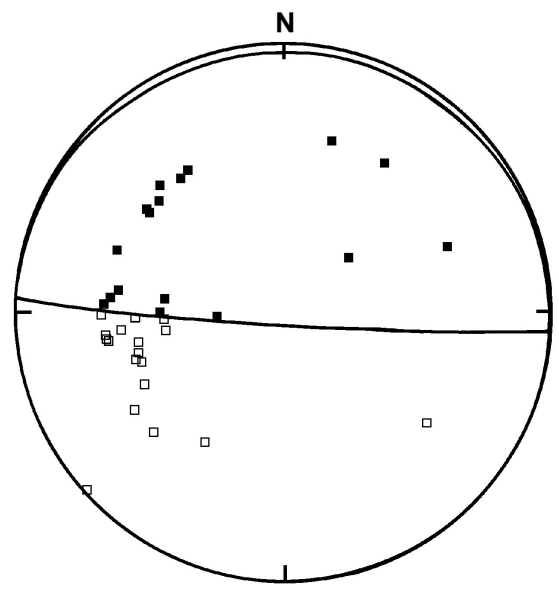

Fig. 17. P-wave first motion focal mechanism of 11 February 1987 event in the Southeast Chersky Range seismic zone of the CSB. Compressional first motions shown in black, dilitations in white (after Riegel, 1994).

This sequence may represent a restraining bend along the Ulakhan fault; the event is too far west to be associated with the Lankova-Omolon fault system (see Fig. 16). Alternatively, it may represent thrusting along faults forming the southeast edge of the zone of primary active deformation of the northwestern Okhotsk plate.

Further northeast, the $M_{S}=4.9$ earthquake of 11 February 1987, near Omsukchan has a very unusual focal mechanism for the area. This event appears to be a very low angle thrust fault along an east-west striking plane (Figs. 16 and 17; Gunbina et al., 1988; Riegel, 1994). The aftershocks align along this plane to the north (Gunbina et al., 1988). Thrust events occurring nearby in Shelikhov Bay (Fig. 16; see below) have more east-west oriented compression and steeper dipping planes.

There is a cluster of seismicity just inland between the settlements of Viliga and Evensk (Fig. 16). The details of this seismicity are poorly known and no focal mechanisms have been determined from this area. These earthquakes could be associated either with a southeastward continuation of the Ulakhan fault or with the Lankova-Omolon fault system, although they are offset from both.

Shelikhov Bay (Fig. 16) is presumed to be under leftlateral transpression (Cook et al., 1986) and appears to be crossed by two or more bands of seismicity. In general, the focal mechanisms here are thrusts with a northeast compression axis, consistent with limited GPS data available from western Kamchatka (Gordeev et al., 2001). The mechanism $\mathrm{m}_{b} 5.1$ event of 22 May 1981 (Figs. 16 and 18; Riegel, 1994) is similar to those of the $M_{w}=5.15$ June 1978 event and the $m_{b} 4.74$ November 1975 event, all in the northernmost band. The details of the seismicity in Shelikhov Bay are still poorly understood due to the lack of seismic stations, poorer epicentral locations, and the lack of published detailed bathymetry.

\section{2}

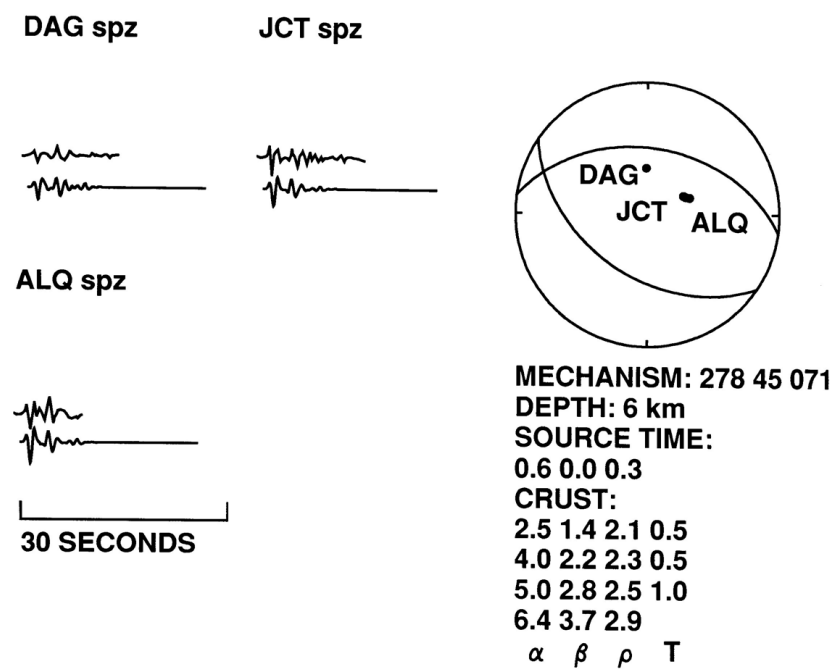

Fig. 18. Synthetic seismograms and focal mechanism of 22 May 1981 event in Southeast Chersky Range seismic zone of the Chersky segment of the CSB. Conventions as in Fig. 6 (after Riegel, 1994).

\subsection{Okhotsk coastal segment}

The seismicity of the Okhotsk Coastal segment (Figs. 16 and 19) adjoins the Chersky Range segment on the north and east and extends along the northern coast of the Sea of Okhotsk. The seismicity is diffuse over a band about $200 \mathrm{~km}$ wide and is presumed to be associated with a number of different faults. Earthquakes of magnitude 5.5-6.5 occurred here in 1851,1931 , and 1936. Earthquakes of $M<4$ occur throughout the zone.

Earthquakes in this area were first felt in 1735 in Okhotsk. However, the largest reported event in the segment was the Yamsk event of 28 November 1851, with an estimated magnitude of 6.5. Mushketov and Orlov (1893) report that "a rather strong earthquake" was felt "along the entire shore of the Sea of Okhotsk" over a distance of about $750 \mathrm{~km}$ from $100 \mathrm{~km}$ west of Magadan to Tuman. In Yamsk (Fig. 16), "a chimney fell down," and "dug-outs were destroyed and the ice on the river was broken."

On 4 January 2001, a magnitude 4.6 earthquake occurred west of Magadan and was followed by several aftershocks. The event was felt in Magadan. Subsequently, on 7 January 2001, a $M_{w}=5.4$ event occurred further to the west; this event was also felt in Magadan. The moment tensor for the latter is consistent with left-lateral motion on a west-northwest striking plane and the epicenter lies along a lineament in the topography of essentially the same strike (Fig. 19). The lineament appears to offset part of a small mountain near $59.48^{\circ} \mathrm{N}$ $146.95^{\circ} \mathrm{E}$ about $1 \mathrm{~km}$ in a left-lateral sense; we interpret this 


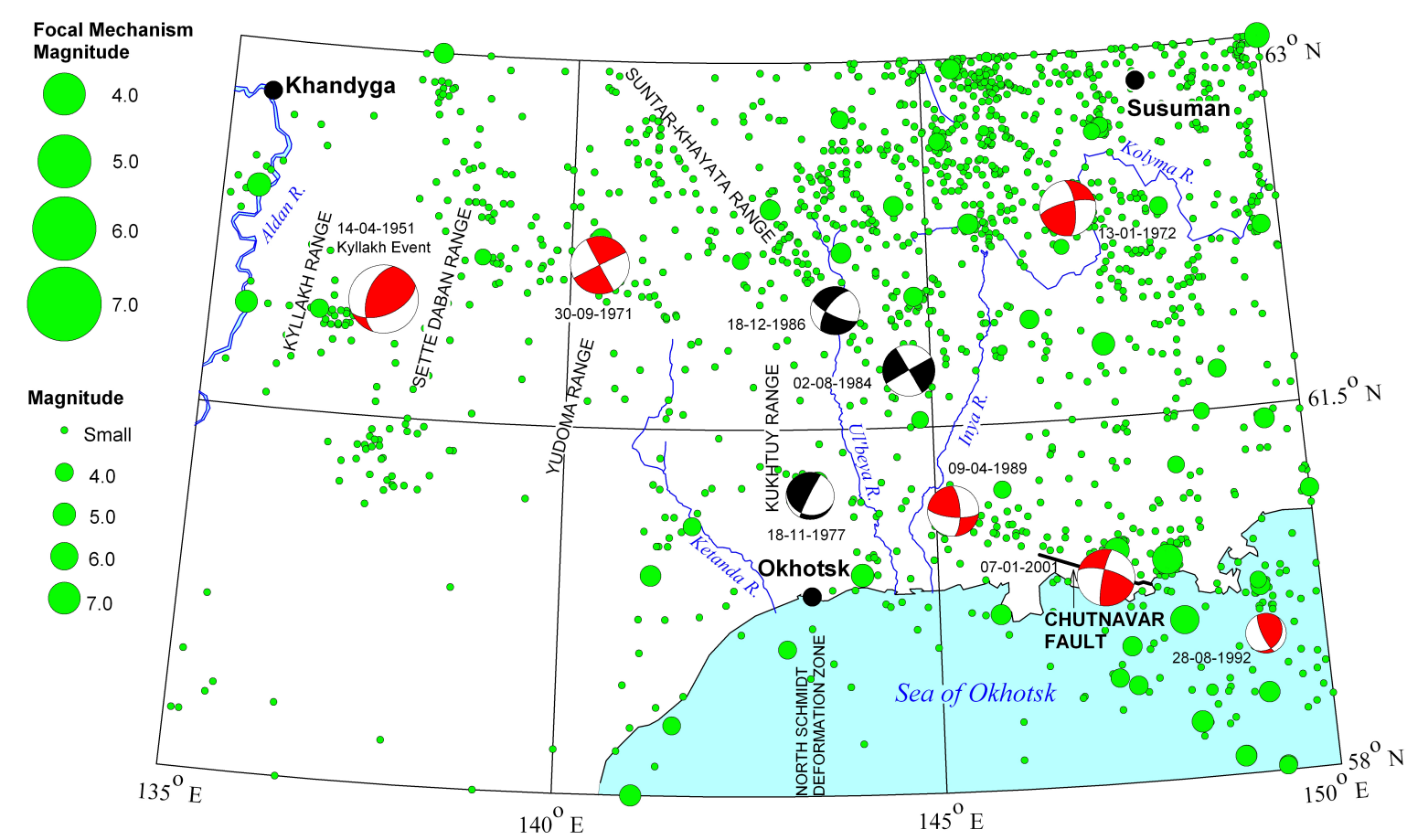

Fig. 19. Seismicity and focal mechanisms of the Ketanda segment and the western part of the Okhotsk Coastal segment of the CSB. Conventions as in Fig. 4.

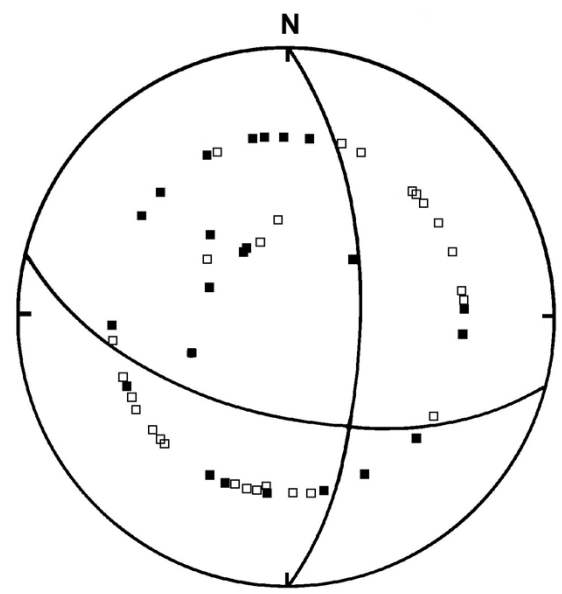

Fig. 20. P-wave first motion focal mechanism of 9 April 1989 event in the Ketanda segment of the CSB. Compressional first motions shown in black, dilitations in white (after Riegel, 1994).

as a fault which we name the Chutnavar fault (Fig. 19) after the mountain range to its south. Other lineaments and presumed faults of the same strike are found in the area (e.g., Grachev, 1997). A band of seismicity parallel to the Chutnavar fault also extends out into the Sea of Okhotsk farther to the south.
Just to the northwest of the 7 January 2001 event, a $M_{S}=4.8$ event with a similar mechanism, although with a greater thrust component (Figs. 19 and 20), occurred on 9 April 1989, approximately along the same lineament. This mechanism is very well constrained based on regional and teleseismic P-wave first motions (Gunbina et al., 1991; Riegel, 1994).

\subsection{Ketanda segment}

The Ketanda segment is located in the Sette Daban and Suntar-Khayata ranges and the basins of the Ketanda, Ul'beya, and Inya Rivers (Fig. 19). The seismicity here merges with the east-west striking Okhotsk segment on the east and the Chersky Segment in the north. The seismicity in the area is relatively weak $(M<4)$ and again diffuse, although the lack of seismic stations in the area has made detection and location difficult. Focal mechanisms suggest a mix of compression and strike-slip motions.

The $m_{b} 5.530$ September 1971 Yudoma event has a well-constrained right-lateral strike-slip mechanism along a northeast-southwest striking plane (Fig. 19 and 21; Koz'min, 1984; Riegel, 1994). This event appears to lie on a secondary fault that is oblique to, and between, several larger north-south striking right-lateral strike slip faults (Riegel et al., 1993) that cross the area and are visible in satellite imagery. 
Other mechanisms in the Ketanda segment, located along its boundary with the Okhotsk Coastal segment are less well constrained but suggest either right-lateral transpression on a north-south striking plane (Ketanda system) or left-lateral strike slip motion on an east west-striking plane (Fig. 19; Gunbina et al., 1991; Riegel et al., 1993).

Imaev et al. (1990) and Riegel et al. (1993) interpret the seismicity of this zone as representing transpression associated with the southward extrusion of the Okhotsk microplate.

A number of events occur along the Nel'kan-Kyllakh thrust system (Fig. 22; Gusev et al., 1976; Gusev, 1979; Prokop'ev, 1989) which overthrusts the rocks of the South Verkhoyansk fold belt over the Siberian platform. The largest event in the area, the Kyllakh event with $M_{w}=6.0$, occurred on 14 April 1951. The event is a nearly pure thrust (Fig. 19; W. Y. Chung and H. Gao, personal communication, 1995) with northwest-southeast directed compression. Small events continue to occur in this area and other magnitude 5 events are known from 1924 and 1958.

\subsection{Eastern Siberian platform}

The eastern part of the Siberian platform is bounded by fault systems, which may be Precambrian structural sutures (Gusev et al., 1976). All of them are presently being reactivated in various degrees and have contemporary movements that are presumed to be controlled by their distance to presentday plate boundaries and the associated plate velocities.

A number of weak events are found along the edge of the Siberian platform north of the lower Aldan River. Some form two linear trends that are perpendicular to the edge of the platform, one north of Bulun settlement (Fig. 1; on the Aldan River), where a magnitude 4.6 event occurred in 1995, and the other southeast of Khandyga.

Generally weak activity (magnitude 1-2 events) is observed within the Siberian platform between the Lena and Aldan Rivers. However, two events in 1956 and 1957 had magnitudes of 4.5-4.8. The 1979 event on the west bank of the Lena, $40 \mathrm{~km}$ north of Yakutsk, with $M=4.2$ may be associated with the geophysically mapped Yakutsk fault (Fig. 1). In 1985, a $M=4.6$ event occurred in a sparsely populated region about $150 \mathrm{~km}$ west of Yakutsk. This event may be linked with the formation of the small uplifts and basins in the Siberian Platform. There are insufficient data to constrain focal mechanisms for these events; however, the few available first motions for the 1985 event are consistent with northsouth compression (Koz'min et al., 1996). One of the fault planes may strike northeast, parallel to dike swarms found in the Kempendyay basin (Fig. 1; Gaiduk, 1988).

\section{Faults}

Mapping and identification of active faults in northeastern Russia through the 1980s was conducted as an outgrowth of geologic mapping using surface field work (Imaev et al.,

\section{0}

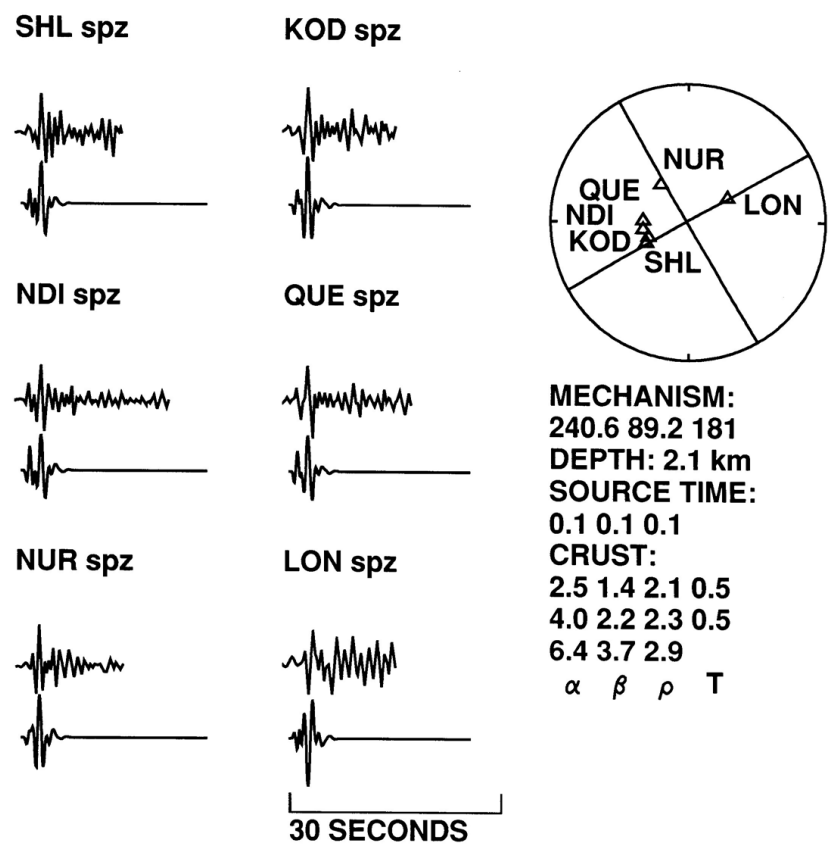

Fig. 21. Synthetic seismograms and focal mechanism of 30 September 1971, Yudoma event in Ketanda segment of the CSB. Conventions as in Fig. 6 (After Riegel, 1994).

1990, 1995). Satellite imagery became generally available to both Russian and western geologists in the early 1990s, with low-cost, high resolution images becoming available in the early years of the 21 st century. These images have resulted in better understanding of the nature and geomorphology of some of the larger faults (Fig. 22).

Faults in the northern part of the study area (Northern Verkhoyansk segment and Northwest Chersky seismic zone), and their relationship to seismicity, have been poorly studied except for a small area in the Kharaulakh Range (Imaev et al., 1990, 1998, 2000) and therefore are not discussed in this paper. We focus our attention on the Chersky Range and adjacent Magadan District where considerable effort has been made by Russian authors to identify recent faulting.

The clearest fault visible in the study area is the Ulakhan fault (Figs. 11 and 22), which can be traced as essentially a straight line for about $1000 \mathrm{~km}$ from the Indigirka River in the northwest to the Seimchan-Buyunda basin in the southeast. A series of lesser faults appear to splay off the Ulakhan (e.g., Darpir; Fig. 11) at various points along its length. The fault marks an edge of the zone of high seismicity and deformation and is considered by many authors to be the edge of the North American plate (e.g., Riegel et al., 1993). It is reflected in both magnetic and gravity fields and dips steeply $\left(70-80^{\circ}\right)$ to the southwest near Bugchan basin (Fig. 22; Imaev et al., 1994). 


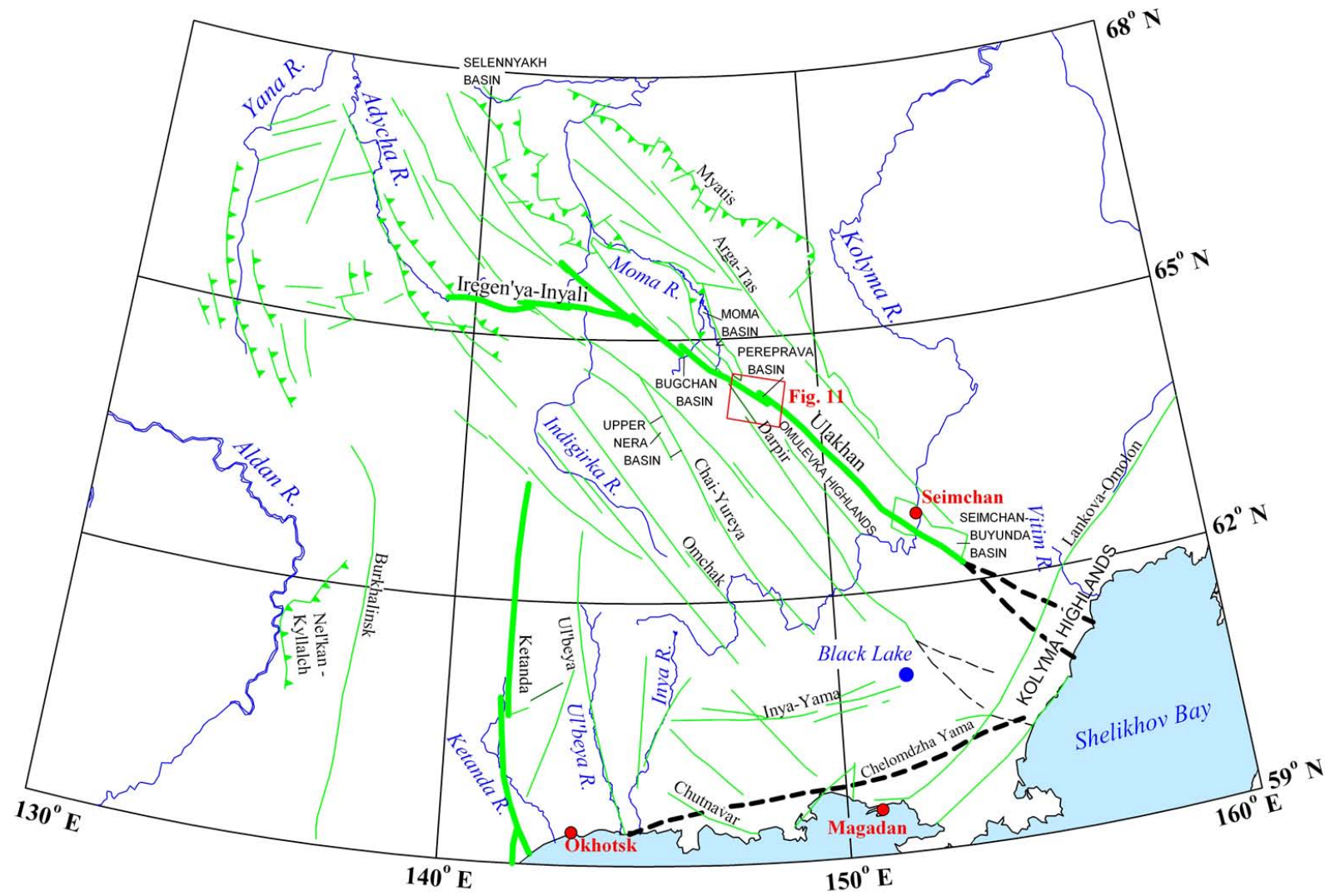

Fig. 22. Map of major faults and lineaments in the Chersky and adjacent segments of the CSB. Dashed lines represent faults whose location or existence is less certain. Thrust faults are shown by toothed lines (teeth on upper plate). Red square shows location of Fig. 11.

The Ulakhan fault is clearly marked in the hydrography by tributaries of the Kolyma, Indigirka, and Moma rivers which are left-laterally offset up to $24 \mathrm{~km}$ (McLean et al., 2000; Fujita et al., 2004, 2006; Mackey et al., 2008) as visible on satellite images (Fig. 11) and Soviet military topographic maps. Smaller offsets of $2-4 \mathrm{~km}$ are observed on streams that cross the Ulakhan fault in the Omulevka Highlands (Mackey and Fujita, 2001). Paleozoic geologic units near the Omulevka Highlands are also offset about the same amount; Mal'kov (1971) proposed that a Cretaceous intrusion is offset $20 \mathrm{~km}$, approximately the same as indicated by the rivers, and Imaev et al. (1994) cite displacement on the fault as being up to $35-40 \mathrm{~km}$. Although the age of the river network is not well known, major rivers are shown following their current drainages on paleogeographic maps published by Vinogradov (1967) starting about the middle Pliocene, and basal deposits in many smaller tributary valleys are Pliocene in age (Krylov, 1971). Therefore, if we assume an age for the river network of 2.5-5.0 million years, horizontal slip along the Ulakhan fault of about $0.5-0.7 \mathrm{~cm} / \mathrm{yr}$ is obtained. This is consistent with end-member modeling of various deformation scenarios investigated by Hindle et al. (2006) that suggest rates of 0.3 to $0.6 \mathrm{~cm} / \mathrm{yr}$.
The northwest termination of the Ulakhan fault west of the Indigirka River may merge with thrusts in the southeastern part of the Northwest Chersky seismic zone. However, the Ulakhan fault appears to bifurcate northeast of Ust' Nera with the majority of the displacement occurring along what McLean et al. (2000) named the Iregen'ya-In'yali fault (Figs. 9 and 22). This fault offsets the Indigirka River leftlaterally by $24 \mathrm{~km}$ (the same displacement as observed on the Ulakhan further east) through a pair of right angle bends, and extends into a series of apparent pull-apart basins along and near the upper course of the Adycha River (Mackey et al., 2008).

On the southeast, the Ulakhan fault is traced along the southern edge of the Seimchan-Buyunda basin where sag ponds and offset terraces are observed in alluvial fans along the south side of the basin (Mackey et al., 2007). Southeast of this basin, the Ulakhan fault is presumed to continue in a roughly east-southeast direction towards Shelikhov Bay and further into Kamchatka (Fig. 22; Savostin and Karasik, 1981; Savostin et al., 1983; Parfenov et al., 1988); however it is not visible in the geomorphology in this region. Some faults imaged by the recent 2-DV reflection profile along the southwest of Omsukchan (Surkov et al., 2003) may be extensions 
of the Ulakhan fault. The multiple bands of seismicity crossing the bay noted above suggest that there are multiple faults along which the relative motion is partitioned in Shelikhov Bay.

Small pull-apart basins are found along inferred (northstepping) releasing bends along the Ulakhan fault. The Bugchan basin (Fig. 22) is an example of such a pull-apart which is filled with variably deformed Miocene-Pliocene deposits cut by northwest-striking faults. Another example is the Pereprava basin (Figs. 11 and 22) located along the Omulevka River which contains deformed Middle to Late Miocene lake deposits (Imaev et al., 1994; Smirnov, 2000). Although it is also possible to interpret the SeimchanBuyunda basin as a pull-apart basin, there is no significant active seismicity within or on the north edge of the basin, and no major fault traceable eastward from its northern edge.

Many landslides and other geomorphological features thought to be due to seismic activity are found along the Ulakhan fault (Imaev et al., 1990, 1995; Vazhenin, 2000). The most prominent of these is the landslide that dammed a small tributary of the Tirekhtyakh River (Fig. 9) and formed a lake approximately 4000 years ago (Vazhenin, 1992, 2000; Imaev et al., 1995).

It is reasonable, based on the seismicity and geomorphological evidence, to view the Ulakhan fault as a major tectonic boundary, possibly the primary fault, separating the North American and Okhotsk plates with left-lateral motion since about Pliocene time.

In contrast, the seismically active Chai-Yureya fault (Fig. 22) is weakly marked in the topography and is difficult to discern in satellite imagery. Several rivers appear to be left-laterally offset by it, but the offsets are small, $\sim 1 \mathrm{~km}$. The Late Jurassic diorite of Mt. Khulamrin (Fig. 13) is apparently cut by the fault and appears to be offset by $8 \mathrm{~km}$, which may be taken as an estimate of maximum displacement. The Chai-Yureya is also believed to bound the Upper Nera basin, a presumed pull-apart basin filled with Oligocene-Neogene deposits (Koz'min, 1984).

Many other presumed strike-slip faults parallel the Ulakhan and Chai-Yureya (Fig. 22; Gusev, 1979; Imaev et al., 1994; Smirnov, 2000). They have been mapped by us using a combination of satellite imagery and geologic evidence. Although their kinematics and levels of activity are presently unknown, we suggest that strain between the North American and Okhotsk plates could be partitioned among many of these faults (see Hindle et al., 2009, this volume). Kozhurin (2004) suggests that the Arga-Tas fault, lying north of the Moma basins, may have had a small amount (100 s of $\mathrm{m})$ of recent right-lateral movement. There is diffuse seismicity that could be associated with some of these faults, but the resolution is not definitive.

The Myatis fault (Fig. 22), which lies to the north of the Ulakhan and is a thrust based on geologic evidence, appears to be weakly seismically active at present; however, no focal mechanisms have been determined for any events that may be associated with it. It is possible that some of the compressional strain between Okhotsk and North America is partitioned onto the Myatis fault, and may have been more significant in the past (Imaev et al., 1990).

The Chelomdzha-Yama fault (Fig. 22) has generally been thought to be the primary active fault along the northern coast of the Sea of Okhotsk (e.g., Imaev et al., 1990), extending from the settlement of Okhotsk to Shelikhov Bay. It is suggested to link a chain of Neogene and Quaternary basins and is reported to be manifested in gravity and magnetic fields (Gusev, 1979; Imaev et al., 1990). The fault is also proposed to represent an old suture within an accreted Mesozoic volcanic arc which has been stitched by Cretaceous plutons (Yudin and Izmailov, 1966). This fault, however, is not at all visible in satellite imagery, although very linear faults parallel to it are clear further inland (e.g., Inya-Yama fault; Fig. 22); the linearity of the latter may indicate that these faults are strike slip, although no significant offset is evident.

Imaev et al. (1994) suggest that the Chelomdzha-Yama fault is left-lateral transpressional, a proposal that was thought to be supported by the 7 January 2001 earthquake in the Okhotsk coastal segment; however, we have noted above that that this event falls along a more localized fault with a different strike, well to the south of the proposed location of the Chelomdzha-Yama fault (Figs. 16 and 22). While undoubtedly an old suture, it is difficult to consider the Chelomdzha-Yama fault as active in the present day based on seismicity, except possibly between Magadan and Yamsk where a cluster of seismicity is noted.

The Lankova-Omolon fault system (Fig. 22) of Smirnov (2000) links a number of Cenozoic basins in the Kolyma Highlands and parallels the coast of Shelikhov Bay for $700 \mathrm{~km}$ to the northeast from Magadan. Smirnov (2000) proposes that it developed in Paleogene time and that it is right-lateral strike slip, but direct seismological evidence is lacking; the seismicity associated with it is weak except between Magadan and Yamsk where it intersects the purported Chelomdzha-Yama fault discussed above. No teleseismic events are directly associated with the fault system. A number of young volcanics are associated with basins along the fault zone, including Late Cenozoic (10-13 Ma) alkali lavas found in the Viliga River region (Figs. 1 and 16; Akinin and Apt, 1997; Leonova et al., 2005). In addition, seismically generated landslides are known in the Tuman Range (Vazhenin, 1992, 2000). Both the volcanics and the landslides lie near the extrapolation of the Ulakhan fault as well and may be associated with it instead. Extrapolation of the Lankova-Omolon fault system into the northern Sea of Okhotsk places it approximately along the edge of recorded microseismicity.

Thus, instead of a single major Chelomdzha-Yama fault, a number of small faults appear to criss-cross the Okhotsk coastal seismic zone with west-northwest (parallel to the Chutnavar fault) and northeast (parallel to the Lankova-Omolon fault) strikes (e.g., Grachev, 1997) and 
may be the sources for much of the diffuse microseismicity of the region.

A series of north-south striking faults (Ketanda, Ul'beya, and others, Fig. 22) cross the Yudoma and Kukhtuy ranges in the Ketanda segment of the CSB. These faults are visible in satellite imagery and are believed to be right-lateral strikeslip faults based on geology (Gusev, 1979; Imaev et al., 1990) and focal mechanisms (Fig. 19). Some transverse faults also exist, such as the presumed source of the 30 September 1971 Yudoma earthquake.

Large north-south faults with unknown present-day kinematics are also found in and near the Sette Daban Range. The largest of these, the Burkhalinsk fault (Fig. 22), is not presently seismically active and may have changed its motions from left- to right-lateral in the Mesozoic and Cenozoic (Prokop'ev, 1989). The Burkhalinsk fault was thought by some (e.g., Riegel et al., 1993) to represent the edge of stable Eurasia, but seismic and satellite imagery point to a fault further east, like the Ketanda, at the present time. Unlike the Ulakhan, the seismicity does not drop abruptly along the Ketanda fault system, but extends diffusely westward toward the Siberian platform, including thrusting in the Kyllakh Range (Fig. 19), the site of the 1951 earthquake.

Many of the faults of the Ketanda system, especially just west of the settlement of Okhotsk, appear to continue southward into the northern Sea of Okhotsk. Geophysical data suggest a zone of faulting with what appear to be positive flower structures (Kashevarov fault, North Schmidt Deformation Zone; Worrall et al., 1996) that continues into northern Sakhalin Island (Fig. 1), where right-lateral strikefaulting is clearly observed (Neftegorsk earthquake of 1995; Jolivet et al., 1992; Fournier et al., 1994; Ivashchenko et al., 1995). Seismicity, however, is absent along the North Schmidt Deformation zone. It may be that the lithosphere here is warm and more ductile as tomographic results of Levin et al. (2002) would suggest, although we can not exclude the possibility of a locked boundary, or simply lack of strain in the area.

Further study of the fault systems of northeast Russia is clearly needed.

\section{Present-day geodynamics}

The pole of rotation between North America and Eurasia is located in the northern Verkhoyansk Range, perhaps as far north as the latitude of Buor-Khaya Bay, although there is some variation in the exact location depending on the method used to determine the pole (Cook et al., 1986; DeMets et al., 1990; Argus and Heflin, 1995; Kogan et al., 2000; Sella et al., 2002; Steblov et al., 2003). This location is consistent with the observed change in focal mechanisms from extension in Buor-Khaya Bay to compression in the northwestern Chersky Range. Additional studies (e.g., Savostin et al., 1985; Cook et al., 1986; Savostin and Drachev, 1988; Rowley and
Lottes, 1988; Gaina et al., 2002) have suggested that the pole of rotation has moved across northeast Russia in the Cenozoic, alternating the stress regime between extension and compression. This may affect the North America-Eurasia poles partially based on transform fault and marine anomaly data averaged over 0.5 to 3.0 million years (e.g., DeMets et al., 1990), and place them further to the south.

Discussions on the recent tectonics of northeastern Russia have often focused on the Moma rift system (e.g., Savostin and Karasik, 1981; Grachev, 1982, 2003; Fujita et al., 1990a, 1990b; Imaev et al., 1995, 2000). The Moma rift system is composed of a chain of small basins (Figs. 5, 9, and 22; Selennyakh, Uyandina, Moma, etc.) separated by narrow uplifts, that traverse northeast Russia roughly parallel to the Chersky seismic belt from the southern end of the Laptev Sea to just east of the Kolyma River (Grachev, 1973, 1987; Fujita et al., 1990b). Based on the age of deposits within them, the basins have been dated as Neogene to Quaternary, perhaps with a few older basal deposits (Fujita et al., 1990b). Most studies suggest the main rifting event to be in Miocene to Pliocene time (Grachev, 1973, 2003).

Although the Seimchan-Buyunda basin (Figs. 9 and 22) is often mapped as part of the Moma system (e.g., Savostin and Karasik, 1981), the presence of Paleogene strata in the basin demonstrates that it has a longer history of development than the other basins of the region (Voskresenskii et al., 1973; Fujita et al., 1990b). The basin has been proposed to have a complex internal structure with several different nested grabens (Bekker et al., 1978; Koshkarev and Kuznetsov, 1986) and may have been active at multiple times.

One group of investigators (Grachev, 1973, 1987, 1999, 2003; Savostin and Karasik, 1981) has used these basins to postulate that most of northeastern Russia is presently under extension with an Euler pole between North America and Eurasia near 60 to $64^{\circ} \mathrm{N}$. In their opinion, the Moma rift is directly linked to extension on the Arctic Mid-Ocean Ridge and is presently active (e.g., Grachev, 1982, 2000, 2003).

A number of geophysical and geological indicators support the existence and recent activity of the rift. Rayleigh waves from earthquakes of the Kuril-Kamchatka arc recorded at Tiksi show that the polarization angle is distorted by up to $40^{\circ}$ along paths crossing the Chersky seismic belt, suggesting the presence of a heterogeneity in the upper mantle (Lander, 1984; Lander et al., 1985). The thickness of the Earth's crust is reduced to $30-35 \mathrm{~km}$ in a band from the Laptev Sea to the upper reaches of the Kolyma River, as compared with surrounding regions where it is $40-45 \mathrm{~km}$ (Mackey et al., 1998), although it is offset to the southwest from the Moma rift system. This region of thin crust is also associated with slightly lower Pn and Pg seismic wave velocities (Mackey et al., 1998, 2003b) and elevated heat flow (up to $100 \mathrm{~mW} / \mathrm{m}^{2}$; Devyatkin, 1993), and hot springs with temperatures up to $20^{\circ} \mathrm{C}$ are found in some of the basins (Grachev, 1987). Very young (as young as $286 \mathrm{Ka}$; Layer et al., 1993) bimodal Cenozoic volcanism is found (Rudich, 
1964; Grachev, 1973, 1987, 2003) in the Moma basin proper (Fig. 9), between the Moma and Chersky Ranges. Paech et al. (1998) note there is very little compressional deformation within the Uyandina basin suggesting that either the current transpressional regime is relatively young, not all basins are undergoing transpressive deformation and/or that the amount of compressional deformation is very small.

The results of focal mechanism analysis however, including the data presented in this paper, indicate that the Chersky Range is at present under transpression (Cook et al., 1986; Parfenov et al., 1988; Fujita et al., 1990a, 1990b; Riegel et al., 1993). Field mapping of faults along some of the basin margins indicate the presence of young reverse and thrust faults (Imaev, 1990, 1991; Imaev et al., 1990, 1995, 2000). The Moma rift basins are also characterized by a very low level of seismicity expressed only by weak events on the flanks of these basins. Thus, it would appear that the Moma rift basins are presently in a compressional setting, and they are essentially inactive.

Analysis of the geodynamic conditions in the Chersky seismic belt show they have changed repeatedly during the Cenozoic and alternated between extension and compression (Savostin and Drachev, 1988). The Moma rift system, therefore, may have developed during an episode when the pole of rotation between North America and Eurasia was located near the coast of the Sea of Okhotsk (Grachev, 1999), placing continental northeast Asia into extension. This extension ended about $0.5 \mathrm{Ma}$ (Cook et al., 1986) when the pole of rotation migrated northward to its present position near the Laptev Sea (Cook et al., 1986; Kogan et al., 2000; Steblov et al., 2003) placing the Chersky Range into compression, but leaving relict volcanic and elevated heat flow activity.

Since the core of the Sea of Okhotsk is aseismic, it has been proposed that the entire Sea of Okhotsk, most of the Magadan district, southern Kamchatka, eastern Sakhalin, and eastern Hokkaido represents a rigid block (Figs. 1 and 23; e.g., Savostin et al., 1982, 1983) that is extruding to accommodate the convergence between North America and Eurasia, with left-lateral motions in the Chersky Range and Shelikhov Bay and right-lateral motions in the Ketanda segment of the CSB and Sakhalin Island (e.g., Riegel et al., 1993). This model and resulting motions are consistent with the seismicity and focal mechanisms of the Ketanda and the Chersky Range segments as discussed in this paper, as well as available GPS data (Steblov et al., 2003) from the Magadan District (Fujita et al., 2004, 2006).

Inversion of GPS data indicates that the northern part of the Okhotsk plate is moving slowly $(\sim 4-5 \mathrm{~mm} / \mathrm{yr})$ southeast with respect to North America (Kogan et al., 2000; Steblov et al., 2003), and slightly faster ( 4-7 mm/yr) and to the south with respect to Eurasia. This is consistent with the extrusion model. Seismicity, however, is concentrated on the North America - Okhotsk boundary with very little on the Okhotsk - Eurasia boundary north of Sakhalin Island. GPS data from Bilibino and Fairbanks also suggest there be some intraplate deformation within the North American plate in northeast Asia and Alaska (Kogan et al., 2000; Sella et al., 2002).

The northern part of the proposed plate (Fig. 23), incorporating most of the Magadan district, has high seismicity and is necessarily a zone of diffuse deformation (e.g., Cook et al., 1986; Imaev et al., 1990; Riegel et al., 1993; Hindle et al., 2006). The interior of this zone of deformation is somewhat less seismic than its borders and it also may be composed of a series of rootless upper-crustal sheets that are being thrust to the south in a manner similar to that suggested by Bobrovnikov and Izmailov (1989), or into a number of thin slices that are extruding (Hindle et al., 2009, this volume); presently available seismic data are insufficient to distinguish or test these models. The locations of the largest earthquakes that have been recorded are generally on the outer edge of the deforming zone which suggests that this deforming region is moving in conjunction with the rest of the Okhotsk plate. The CSB and the Moma rift system both align crudely with the accretionary boundary between the KolymaOmolon superterrane and the Siberian continent (Parfenov, 1991). As a result, it is likely that much of the deformation in the CSB is exploiting pre-existing zones of weakness.

The northwest apex of the Okhotsk plate as usually defined is located north of Ust' Nera near the Indigirka River, where the sense of the strike-slip component along the strike of the Chersky seismic belt appears to change from right-lateral to left-lateral (c.f., focal mechanisms of the 9 September 1968 and 18 May 1971 events) and may represent a "triple junction" between the Okhotsk, Eurasian, and North American plates (Fig. 23); the senses of motion are the opposite of what would occur due to oroclinal bending. We note that as a result of the extrusion, the "triple junction" is not fixed and is presumably migrating southeastward.

The microseismicity associated with the faults of the Okhotsk coastal seismic zone and the Lankova-Omolon fault system (Fig. 22) suggests, however, that much of the northern and seismically very active part of the Okhotsk plate is somewhat decoupled from the rest of it. One model, which could account for the difficulty of tracing the Ulakhan fault southeast of the Seimchan-Buyunda basin is that the on-land portion of the plate is being thrust over, or into, the rest of the Okhotsk plate to the south. This is supported by topographic and geomorphological evidence that suggests that the region adjacent to the Sea of Okhotsk is undergoing uplift. The drainage divide between the Sea of Okhotsk and the Arctic Ocean is disproportionately close, or even along the coast of, the Sea of Okhotsk. The drainage divide is migrating south as north-flowing streams are consistently capturing the heads of south flowing streams. A clear example of this occurs about $2 \mathrm{~km}$ north of Black Lake north of Magadan (Fig. 16). The on-land northwestern part of the Okhotsk plate is composed of more heterogeneous material as a result of its Mesozoic accretionary history (e.g., Nokleberg et al., 2000) and may deform more easily than the rigid core of the Okhotsk plate to the south. This model requires that the faults of the Okhotsk 


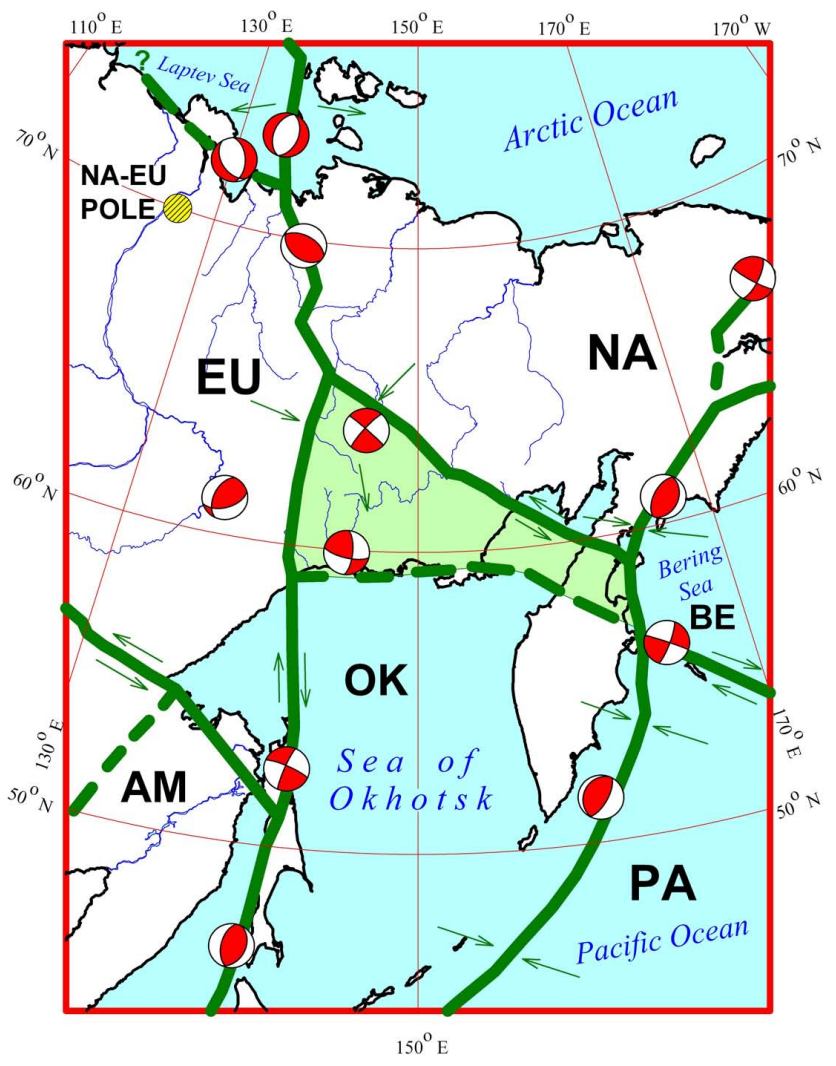

Fig. 23. Generalized tectonic map of northeastern Russia. Solid green lines show boundaries of major plates and blocks. Dashed lines show minor boundaries and the light green shaded area represents the limits of the region of high deformation in the northern Okhotsk plate. Arrows show directions of relative plate motion. Representative focal mechanisms are shown as lower hemisphere projections with the compressional quadrants shaded. Approximate location of North America - Eurasia pole is shown by shaded yellow dot.

coastal seismic zone and the Lankova-Omolon fault system have some compressional component, which has not yet been documented in seismic data.

We note that Seno et al. (1996), as well as some recent GPS-based studies (e.g., Apel et al., 2006), suggest that if there is an independent Okhotsk plate, the Eurasia - Okhotsk pole of rotation must be located near northern Sakhalin with extension to the north and compression to the south. Geologic and focal mechanism data cited above, as well as the CMT mechanism of a $M_{w}=4.8$ earthquake that occurred on 11 September 2006 , at $55.5^{\circ} \mathrm{N}$, north of Sakhalin, strongly suggest that the Ketanda fault system is right-lateral and that the region north of Sakhalin is today under transpression. This discrepancy may be due to differences in deformation and relative motions in the southern and eastern parts of the Okhotsk plate due to a greater impact of the far-field effects of the India-Eurasia collision on the southern part of Sakhalin Island (or at least the eastward motion of the Amur block), where most GPS and seismotectonic data are obtained. Alternatively, the northern zone of deformation may be even more decoupled from the core of the Okhotsk plate than envisioned in this paper. It is possible that southeastward extrusion of the northern part of the Okhotsk plate, as it undergoes compression between North America and Eurasia, is imparting a clockwise rotation to the more rigid core. Currently available data are insufficient to resolve this question.

\section{Conclusions}

The Chersky seismic belt represents a zone of intense deformation between the North American and Eurasian plates. It changes from extension in the Laptev Sea to transpression within and south of the Chersky Range. The zone of deformation is bounded by two major fault systems - the Ulakhan system on the north, and the somewhat less well defined Ketanda system on the west. Focal mechanisms indicate left-lateral strike-slip motion on the Ulakhan and associated faults and right-lateral motion on the Ketanda and associated faults, consistent with the southeastward extrusion of an Okhotsk plate. However, the high level of active seismicity in the Magadan district distinguishes it from the rest of the Okhotsk plate proper and may indicate that the region is undergoing greater deformation and is somewhat decoupled from the rest of the plate. The details of the strain partitioning, active faulting, relationship of seismicity to specific faults, and the existence and movement of mini-blocks in the Chersky seismic belt are poorly determined and await further seismological and field study.

Acknowledgements. The US authors wish to thank the late Leonid M. Parfenov for introducing us to this fascinating area, his support, and for many years of fruitful and productive discussions. We are grateful to the members of the Yakut and Magadan EMSDs for their assistance in obtaining data and providing logistical support over the past 15 years; in particular we thank the late Alexander F. Pivkin of the Seimchan seismic station for his hospitality and his sharing geologic knowledge. We thank Giovanni Sella and Seth Stein for discussions on GPS data on the region and Tetsuzo Seno and David Hindle for extensive discussions on the question of the Okhotsk plate. MSU graduate students David B. Cook, Cindy A. McMullen, and Daniel K. Olson conducted initial work on the focal mechanisms of this region; Maisie L. Nichols helped with data entry. We thank Glenn C. Kroeger for use of his synthetic seismogram software and Emile A. Okal for assistance with the Artyk earthquake relocation study. We thank Mikhail G. Kogan, Natalia A. Ruppert, Brian A. Hampton, and David B. Stone for helpful reviews and comments. US research was supported by the Incorporated Research Institutions for Seismology subawards 158, 159, and 243, Michigan State University, the Geophysical Institute of the University of Alaska Fairbanks, National Science Foundation grants OPP 90-23580, 92-24193, 94-24139, and 98-06130, Defense Threat Reduction Agency contract DSWA01-98-C-0168, and US Department of Energy contracts DE-FC03-02SF22490 and DE-FC52-2004NA25540. Russian research was supported by the 
Russian Academy of Sciences and the Russian Fund for Basic Research. Final manuscript preparation was assisted, in part, by National Science Foundation grant EAR 01-25787 to the University of Washington.

\section{References}

Akinin, V. V. and Apt, Y. E.: Late Cenozoic alkali-basic volcanism in northeast Russia, in: Magmatism and Mineralization in Northeast Russia, edited by: Byalobzheskii, S. G., SVKNII DVO RAN, Magadan, 155-174, 1997 (in Russian).

Apel, E. V., Bürgmann, R., Steblov, G., Vasilenko, N., King, R., and Prytkov, A.: Independent active microplate tectonics of northeast Asia from GPS velocities and block modeling, Geophys. Res. Lett., 33, L11303, doi:10.1029/2006GL026077, 2006.

Argus, D. F. and Heflin, M. B.: Plate motion and crustal deformation estimated with geodetic data from the Global Positioning System, Geophys. Res. Lett., 22, 1973-1976, 1995.

Artamonov, V. V. and Mishina, L. V.: Recording capabilities of the seismic station network in the northeast USSR, in: Seismic Processes in the Northeast USSR, edited by: Shilo, N. A., Vashchilov, Y. Y., Lin'kova, T. I., and Akhlamova, N. N., SVKNII DVO AN SSSR, Magadan, 99-115, 1984 (in Russian).

Avetisov, G. P.: Seismicity of the Laptev Sea and its connection with the seismicity of the Eurasia basin, Tektonika Arktiki, 1, 31-36, 1975 (in Russian).

Avetisov, G. P.: Hypocenters and focal mechanisms of earthquakes of the Lena River delta and its surroundings, Vulkanologiya i Seismologiya, 1991(6), 59-69, 1991 (in Russian).

Avetisov, G. P.: Some aspects of lithospheric dynamics of Laptev Sea, Izv.-Phys. Solid Eart+, 29, 402-412, 1993.

Avetisov, G. P.: Seismoactive Zones of the Arctic, VNIIOkeanologiya, Sankt Peterburg, 1996 (in Russian).

Avetisov, G. P.: Yet again on the earthquakes of the Laptev Sea, Geologo-Geofizichiskie Kharakhteristiki Litosfery Arkticheskogo Regiona, 3, 104-113, 2000 (in Russian).

Balakina, L. M., Vvedenskaya, A. V., Golubeva, N. V., Misharina, L. A., and Shirokova, E. I.: Field of the Earth's Elastic Stresses and Mechanism of Earthquake Foci, Nauka, Moscow, 1972 (in Russian).

Balakina, L. M., Zakharova, A. I., Moskvina, A. G., and Chepkunas, L. S.: Investigations of focal mechanisms of strong crustal earthquakes of northern Eurasia, 1927-1991, Seismichnost' i Seismicheskoe Raionirovanie Severnoi Evrazii, 1, 123131, 1993 (in Russian).

Bekker, A. G., Palymskii, B. F., Sharafan, V. Y., and Kirsanov, A. N.: On the structure and gold potential of the Seimchan-Buyunda basin, Materialy po Geologii i Poleznym Iskopaemym SeveroVostoka SSSR, 24, 112-118, 1978 (in Russian).

Biswas, N. N., Pujol, J., Tytgat, G., and Dean, K.: Synthesis of Seismicity Studies for Western Alaska, Final Report for NOAA Contract NA81-RAC00112, Geophysical Institute, University of Alaska, Fairbanks, 1983.

Bobrovnikov, V. A. and Izmailov, L. I.: Present-day structure and geodynamics of the Earth's crust of the southeastern part of the Yana-Kolyma system, in: Geophysical Investigations for the Solution of Geologic Problems, edited by: Lin'kova, T. I. and Krasnyi, L. L., SVKNII DVO AN SSSR, Magadan, 5-23, 1989 (in Russian).
Bourgeois, J., Pinegina, T. K., Ponomareva, V., and Zaretskaya, N.: Holocene tsunamis in the southwestern Bering Sea, Russian Far East, and their tectonic implications, Geol. Soc. Am. Bull., 118, 449-463, 2006.

Chapman, M. E. and Solomon, S. C.: North American Eurasian plate boundary in northeast Asia, J. Geophys. Res., 81, 921-930, 1976.

Cochran, J. R., Kurras, G. J., Edwards, M. H., and Coakley, B. J.: The Gakkel Ridge: Bathymetry, gravity anomalies, and crustal accretion at extremely slow spreading rates, J. Geophys. Res., 108(B2), 2116, doi:10.1029/2002JB001830, 2003.

Cook, D. B.: Seismology and Tectonics of the North American Plate in the Arctic: Northeast Siberia and Alaska, Ph.D. dissertation, Michigan State University, East Lansing, 1988.

Cook, D. B., Fujita, K., and McMullen, C. A.: Present-day plate interactions in northeast Asia: North American, Eurasian, and Okhotsk plates, J. Geodyn., 6, 33-51, 1986.

DeMets, C., Gordon, R. G., Argus, D. F., and Stein, S.: Current plate motions, Geophys. J. Int., 101, 425-478, 1990.

DeMets, C.: A test of present-day plate geometries for northeast Asia and Japan, J. Geophys. Res., 97, 17 627-17 635, 1992.

Devyatkin, V. N.: Heat Flow of the Cryolitic Zone of Siberia, Nauka, Novosibirsk, 1993 (in Russian).

Drachev, S. S., Savostin, L. A., Groshev, V. G., and Bruni, I. E.: Structure and geology of the continental shelf of the Laptev Sea, eastern Russian Arctic, Tectonophysics, 298, 357-393, 1998.

Dziewonski, A. M., Chou, T.-A., and Woodhouse, J. H.: Determination of earthquake source parameters from waveform data for studies of global and regional seismicity, J. Geophys. Res., 86, 2825-2852, 1981.

Dziewonski, A. M., Ekstrom, G., Franzen, J. E., and Woodhouse, J. H.: Global seismicity of 1980: centroid-moment tensor solutions for 515 earthquakes, Phys. Earth Planet. In., 50, 127-154, 1988.

England, P. and Jackson, J.: Active deformation in the continents, Annu. Rev. Earth Pl. Sc., 17, 197-226, 1989.

Filson, J. and Frasier, C. W.: The source of a Siberian earthquake, EOS T. Am. Geophys. Un., 53, 1041, 1972.

Fournier, M., Jolivet, L., Huchon, P., Sergeyev, K. F., and Oscorbin, L. S.: Neogene strike-slip faulting in Sakhalin and the Japan Sea opening, J. Geophys. Res., 99, 2701-2725, 1994.

Franke, D., Krüger, F., and Klinge, K.: Tectonics of the Laptev Sea - Moma "Rift" region: investigation with seismologic broadband data, J. Seismol., 4, 99-116, 2000.

Fujita, K.: Peaceful nuclear explosions in the Sakha Republic (Yakutia), Russia, Seismol. Res. Lett., 66(3), 20-24, 1995.

Fujita, K., Cook, D. B., Hasegawa, H., Forsyth, D., and Wetmiller, R.: Seismicity and focal mechanisms of the Arctic region and the North American plate boundary in Asia, in: The Geology of North America, v. L., The Arctic Ocean Region, edited by: Grantz, A., Johnson, G. L., and Sweeney, J. F., Geological Society of America, Boulder, 79-100, 1990a.

Fujita, K., Cambray, F. W., and Velbel, M. A.: Tectonics of the Laptev Sea and Moma rift systems, northeastern USSR, Mar. Geol., 93, 95-118, 1990b.

Fujita, K., Stone, D. B., Layer, P. W., Parfenov, L. M., and Koz'min, B. M.: Cooperative program helps decipher tectonics of northeast Russia, EOS T. Am. Geophys. Un., 78(24), 245, 252-253, 1997. 
Fujita, K., Mackey, K. G., Gunbina, L. V., and Koz'min, B. M.: Explosion contamination of the northeast Siberian earthquake catalog: Implications for natural seismicity distributions, EOS T. Am. Geophys. Un., 79(45), suppl., F603, 1998.

Fujita, K., Mackey, K. G., McCaleb, R. C., Gunbina, L. V., Kovalev, V. N., Imaev, V. S., and Smirnov, V. N.: The seismicity of Chukotka, northeast Russia, Geol. Soc. Am. Spec. Pap. 360, 259-272, 2002a.

Fujita, K., McLean, M. S., Mackey, K. G., and Koz'min, B. M.: The 1971 Artyk earthquake: Is the locus of motion changing in northeast Russia?, EOS T. Am. Geophys. Un., 83(47), suppl., F1247, 2002b.

Fujita, K., Sella, G., Mackey, K. G., Stein, S., Park, K.-D., and Imaev, V. S.: Relationships between seismicity and GPS determined velocities in northeast Asia, EOS T. Am. Geophys. Un., 85(47), suppl., F667, 2004. Poster published in Stone, D., comp., Origin of Northeastern Russia: Paleomagnetism, Geology, \& Tectonics, University of Alaska, Geophysical Institute Rep. UAG-R-330, CD, 2006.

Gaiduk, V. V.: Vilyui Middle Paleozoic Rift System, Yakutskii Filial SO AN SSSR, Yakutsk, 1988 (in Russian).

Gaina, C., Roest, W. R., and Müller, R. D.: Late CretaceousCenozoic deformation of northeast Asia, Earth Planet. Sc. Lett., 197, 273-286, 2002.

Global CMT Catalog (formerly Harvard CMT Catalog): Global CMT Web Page, available at: http://www.globalcmt.org, 2008.

Godzikovskaya, A. A.: Local Explosions and Earthquakes, EES Rossii, Moscow, 1995 (in Russian).

Godzikovskaya, A. A.: Local Explosions and Earthquakes, EES Rossii, Moscow, 2nd edn., 2000 (in Russian).

Godzikovskaya, A. A. and Lander, A. V.: Are mantle earthquakes possible on Chukotka? Izv.-Phys. Solid Eart+, 27, 1084-1086, 1991.

Gordeev, E. I., Gusev, A. A., Levin, V. E., Bakhtiarov, V. F., Pavlov, V. M., Chebrov, V. N., and Kasahara, M.: Preliminary analysis of deformation at the Eurasia-Pacific-North America plate junction from GPS data, Geophys. J. Int., 147, 189-198, 2001.

Gordon, R. G.: The plate tectonic approximation: Plate nonrigidity, diffuse plate boundaries, and global plate reconstructions, Annu. Rev. Earth Planet. Sc., 26, 615-642, 1998

Grachev, A. F.: Moma continental rift, Geofizicheskie Metody Razvedki v Arktike, 8, 56-75, 1973 (in Russian).

Grachev, A. F.: Geodynamics of the transitional zone from the Moma rift to the Gakkel ridge, Am. Assoc. Petr. Geol. Mem., 34, 103-113, 1982.

Grachev, A. F.: Rift Zones of the Earth, Nedra, Moscow, 2nd edn., 1987 (in Russian).

Grachev, A. F. (Ed.): Neotectonic Map of Northern Eurasia, Dept. Inform. Syst., VNIIZarbuzhgeologiya, 6 sheets, scale 1:5000 000, 1997.

Grachev, A. F.: Quaternary volcanism and problems of geodynamics in northeast Asia, Izv.-Phys. Solid Eart+, 35, 705-722, 1999.

Grachev, A. F.: Regions of continental rifting, Moma rift, rift structures of the Laptev Sea shelf and problems of the boundary between the North American and Eurasian lithospheric plates, in: Neotectonics, Geodynamics, and Seismicity of Northern Eurasia, edited by: Grachev, A. F., PROBEL, Moscow, 185-205, 2000 (in Russian).
Grachev, A. F.: The Arctic rift system and the boundary between the Eurasian and North American lithospheric plates: New insight to plate tectonic theory, Russ. J. Earth Sc., 5, 307-345, 2003.

Gramberg, I. S., Demenitskaya, R. M., and Sekretov, S. B.: System of rift grabens of the Laptev Sea shelf as a missing link of the rift belt of the Gakkel Ridge - Moma Rift, Dokl. Akad. Nauk SSSR+, 311, 689-694, 1990 (in Russian).

Gunbina, L. V., Vorob'eva, E. A., and Bobkov, A. O.: Omsukchan Earthquake of 11 February, 1987, IMGiG DVO AN SSSR, Yuzhno Sakhalinsk, 1988 (in Russian).

Gunbina, L. V., Efremova, L. V., Bobkov, A. O., and Rudik, M. I.: Okhotsk Earthquake of 9 April, 1989, SVKNII DVO AN SSSR, Magadan, 1991 (in Russian).

Gusev, G. S.: Folded Structures and Faults of the VerkhoyanskKolyma System of Mesozoides, Nauka, Moscow, 1979 (in Russian).

Gusev, G. S., Mokshantsev, K. B., and Tret'yakov, F. F.: Faults of the Verkhoyansk-Chukotka folded region, in: Fault Tectonics of the Territory of the Yakut ASSR, edited by: Mokshantsev, K. B., Izdanie Yakutskogo Filiala SO AN SSR, Yakutsk, 73-114, 1976 (in Russian).

Heki, K., Miyazaki, S., Takahashi, H., Kasahara, M., Kimata, F., Miura, S., Vasilenko, N. F., Ivashchenko, A., and An, K.-D.: The Amurian plate motion and current plate kinematics in eastern Asia, J. Geophys. Res., 104, 29 147-29 155, 1999.

Hindle, D., Fujita, K., and Mackey, K.: Current deformation rates and extrusion of the northwestern Okhotsk plate, northeast Russia, Geophys. Res. Lett., 33, L02306, doi:10.1029/2005GL024814, 2006.

Hindle, D., Fujita, K., and Mackey, K.: Deformation of the northwestern Okhotsk plate. How is it happening?, Stephan Mueller Spec. Publ. Ser., this volume, 2009.

Imaev, V. S.: Cenozoic thrusts and fold deformation in the Moma basin system, Geol. Geofiz., 1990(7), 118-123, 1990 (in Russian).

Imaev, V. S.: Late Cenozoic overthrusts, reverse faults and folded dislocations of the Chersky seismic belt (eastern Yakutia), Geotectonics, 25, 356-361, 1991.

Imaev, V. S., Imaeva, L. P., and Koz'min, B. M.: Active Faults and Seismotectonics of Northeast Yakutia, Yakutskii Nauchnyi Tsentr SO AN SSSR, Yakutsk, 1990 (in Russian).

Imaev, V. S., Imaeva, L. P., Koz'min, B. M., and Fujita, K.: Active faults and recent geodynamics of Yakutian seismic belts, Geotectonics, 28, 146-158, 1994.

Imaev, V. S., Imaeva, L. P., and Koz'min, B. M.: Seismotectonic dislocations in seismic belts of Yakutia, Geotectonics, 29, 73 86, 1995.

Imaev, V. S., Imaeva, L. P., and Koz'min, B. M.: Stress-deformation conditions of the Earth's crust in the transition zone from ocean to continent in the Arctic part of Yakutia, Otechestv. Geol., 1998(6), 14-18, 1998 (in Russian).

Imaev, V. S., Imaeva, L. P., and Koz'min, B. M.: Seismotectonics of Yakutia, GEOS, Moscow, 2000 (in Russian).

Ivashchenko, A. I., Kuznetsov, D. P., Kim, C. U., Oskorbin, L. S., Poplavskaya, L. N., Poplavskii, A. A., Burymskaya, R. N., Mikhailova, T. G., Strel'tsov, M. I., Sholokhova, A. A., Davydova, N. A., Nagornykh, T. V., Ovchinnikov, V. V., Sadchikova, A. A., Sen, R. S., Kharlamov, A. A., Shalgin, S. V., Fokina, T. A., Efimov, S. A., Khritova, L. I., Koikova, L. F., and Levin, Y. 
N.: Neftegorsk earthquake of 27(28) May, 1995, on Sakhalin, in: Federal System of Seismological Observations and Earthquake Prediction, Special Issue, Neftegorsk Earthquake of 27(28) May, 1995, edited by: Strakhov, V. N., MChS Rossii, Moscow, 48-67, 1995 (in Russian).

Jackson, J. and McKenzie, D.: The relationship between plate motions and seismic moment tensors, and the rates of active deformation in the Mediterranean and Middle East, Geophys. J. Roy. Astr. S., 93, 45-74, 1988.

Jemsek, J. P., Bergman, E. A., Nabelek, J. L., and Solomon, S. C.: Focal depths and mechanisms of large earthquakes on the Arctic mid-ocean ridge system, J. Geophys. Res., 91, 13 993-14005, 1986.

Jolivet, L., Fournier, M., and Huchon, P.: Cenozoic intracontinental dextral motion in the Okhotsk-Japan Sea region, Tectonics, 11, 968-977, 1992.

Khromovskikh, V. S., Solonenko, V. P., Semenov, R. M., and Zhilkin, V. M.: Paleoseismogeology of the Greater Caucasus, Nauka, Moscow, 1979 (in Russian).

Kim, B. I.: Structural continuation of the rift valley of Gakkel Ridge on the Laptev shelf, in: Structure and History of Development of the Arctic Ocean, edited by: Egiazarov, B. K. and Kazmin, Y. B., Sevmorgeologiya, Leningrad, 133-139, 1986 (in Russian).

Kochetkov, B. M.: Seismicity of Yakutia, Nauka, Moscow, 1966 (in Russian).

Kogan, M. G., Steblov, G. M., King, R. W., Herring, T. A., Frolov, D. I., Egorov, S. G., Levin, V. Y., Lerner-Lam, A., and Jones, A.: Geodetic constraints on the rigidity and relative motion of Eurasia and North America, Geophys. Res. Lett., 27, 2041-2044, 2000.

Koshkarev, V. L. and Kuznetsov, V. M.: On the problem of the formation of deposits in neotectonic basins (according to geologicgeophysical data), in: Actual Problems of the Geology of Deposits of Mineral Resources of the Northeast USSR, Ministerstvo Geologii RSFSR, Moscow, 102-111, 1986 (in Russian).

Kovachev, S. A., Kuzin, I. P, and Soloviev, S. L.: Short-term study of microseismicity in the Guba Buorkhaya, Laptev Sea, using ocean bottom seismographs, Izv.-Phys. Solid Eart+, 30, 647658, 1994.

Kovalev, V. N. (Ed.): Study of the Seismic Regime of the Territory of the Northeast of the USSR (Report on Work Conducted by EMSD NEISRI in 1990), SVKNII, Magadan, 1991 (in Russian).

Kovalev, V. N. (Ed.): Study of the Seismic Regime of the Territory of Northeast Russia (Report on Work Conducted by EMSD NEISRI in 1992), SVKNII, Magadan, 1993 (in Russian).

Kozhurin, A. I.: Active faulting at the Eurasian, North American and Pacific plates junction, Tectonophysics, 380, 273-285, 2004.

Koz'min, B. M.: Seismic Belts of Yakutia and the Focal Mechanisms of Their Earthquakes, Nauka, Moscow, 1984 (in Russian).

Koz'min, B. M.: Earthquakes of Yakutia, in: Earthquakes in the USSR in 1984, edited by: Kondorskaya, N. V., Nauka, Moscow, 146-150, 1987 (in Russian).

Koz'min, B. M., Andreev, T. A., Dareshkina, N. M., Yugova, R. S.: Earthquakes of Yakutia and the Northeast, in: Earthquakes of the USSR in 1972, edited by: Gorbunova, I. V., Kondorskaya, N. V., and Shebalin, I. V., Nauka, Moscow, 119-131, 1976 (in Russian).

Koz'min. B. M., Imaev, V. S., Imaeva, L. P., Fujita, K., Chung, W.-Y., and Gao, H.: Seismicity and active faults of the eastern
Siberian platform, EOS T. Am. Geophys. Un., 77(46), suppl., p. F521, 1996.

Kroeger, G. C.: Synthesis and Analysis of Teleseismic Body Wave Seismograms, Ph.D. dissertation, Stanford University, Stanford, 1987.

Krylov, I. I.: Geological factors in the course changes of a system of river valleys in mountain regions (exemplified by the headwaters of the Kolyma and Indigirka Rivers), Sov. Hydrol., Selected Papers, 6, 562-565, 1971.

Lander, A. V.: Anomalous phenomena in surface waves in northeast Eurasia and their relation to the region of the Moma rift, Quant. Seismol., 16, 124-150, 1984.

Lander, A. V., Levshin, A. L., Ratnikova, L. I., and Yakobson, A. N.: Characteristics of the structure of north Eurasia at depth as indicated by surface seismic wave data, Dokl. Earth Sci., 285, 33-36, 1985.

Layer, P., Parfenov, L. M., Surnin, A. A., and Timofeyev, V. F.: First 40Ar-39Ar ages of igneous and metamorphic rocks from the Upper Yana-Kolyma Mesozoides, Dokl. Earth Sci., 330, 130-134, 1993.

Lazareva, A. P. and Misharina, L. A.: Stresses in earthquake foci in the Arctic Seismic Belt, Izv.-Phys. Solid Eart+, 1965(2), 84-87, 1965.

Leonova, V. V., Vol'f, Y. V., and Akinin, V. V.: Late Cenozoic alkali lavas from Viliga river area (Northern Priokhotie), in: Science in Northeast Russia at the Beginning of the Century, edited by: Chereshnev, I. A., SVKNII DVO RAN, Magadan, 109-11, 2005 (in Russian).

Levin, V., Shapiro, N., Park, J., and Ritzwoller, M.: Seismic evidence for catastrophic slab loss beneath Kamchatka, Nature, 418, 763-767, 2002.

Mackey, K. G.: Seismological Studies in Northeast Russia, Ph.D. dissertation, Michigan State University, East Lansing, 1999.

Mackey, K. G. and Fujita, K.: The northeast Russia seismicity database and explosion contamination of the Russian earthquake catalog, in: Proceedings of the $21^{s t}$ Seismic Research Symposium: Technologies for monitoring the Comprehensive NuclearTest-Ban Treaty, US Department of Defense, 1, LA-UR-994700, 151-161, 1999.

Mackey, K. G. and Fujita, K.: Event relocations and seismic calibration in northeast Russia, in: $22^{\text {nd }}$ Annual DoD/DOE Seismic Research Symposium: Planning for Verification of and Compliance with the Comprehensive Nuclear-Test-Ban Treaty (CTBT), Proceedings, US Department of Defense, Dulles, VA, 2, 223232, 2000.

Mackey, K. and Fujita, K.: Seismic calibration and discrimination in northeast Russia, in: Proceedings of the $23^{r d}$ Seismic Research Review: Worldwide Monitoring of Nuclear Explosions, National Nuclear Safety Administration, US Department of Energy, 1, 80-89, 2001.

Mackey, K. G., Fujita, K., Gunbina, L. V., Kovalev, V. N., Imaev, V. S., Koz'min, B. M., and Imaeva, L. P.: Seismicity of the Bering Strait region: Evidence for a Bering Sea block, Geology, 25, 979-982, 1997.

Mackey, K. G., Fujita, K., and Ruff, L. J.: The crustal thickness of northeast Russia, Tectonophysics, 284, 283-297, 1998.

Mackey, K. G., Fujita, K., Gounbina, L., Koz'min, B., Imaev, V., Imaeva, L., and Sedov, B.: Explosion contamination of the northeast Siberian seismicity catalog: implications for natural earth- 
quake distributions and the location of the Tanlu fault in Russia, B. Seismol. Soc. Am., 93, 737-746, 2003a.

Mackey, K. G., Fujita, K., Hartse, H. E., and Steck, L. K.: Seismic regionalization in northeast Russia, in: Proceedings of the $25^{\text {th }}$ Seismic Research Review: Nuclear Explosion Monitoring: Building the Knowledge Base, National Nuclear Safety Administration and Department of Energy, 1, 73-82, 2003b.

Mackey, K., Fujita, K., Hartse, H. E., Steck, L. K., Gounbina, L., Leyshuk, N., Shibaev, S., Koz'min, B., Imaev, V., Gordeev, E., Masalski, O., Gileva, N., Bormotov, V. A., and Voitenok, A. A.: Seismicity of Eastern Russia 1960-2004, LAUR-04-1381, 1 sheet, 2005.

Mackey, K. G., Hampton, B. A., Fujita, K., Kurtkin, S., and Gounbina, L. V.: Active faulting along the Ulakhan Fault, SeimchanBuyunda basin, northeast Russia, EOS T. Am. Geophys. Un., 88(52), suppl., T13D-1579, 2007.

Mackey, K., Steck, L., Fujita, K., Hartse, H., and Stead, R.: Seismic characterization of northeast Asia, in: Proceedings of the $30^{\text {th }}$ Monitoring Research Review - Ground-Based Nuclear Explosion Monitoring Technologies, National Nuclear Security Administration and Air Force Research Laboratory, 1, 122-131, 2008.

Mackey, K. G., Fujita, K., Sedov, B. M., Gounbina, L. V., and Kurtkin, S.: A seismic swarm in Neshkan, Chukotka, northeastern Russia and implications for the boundary of the Bering Plate, Stephan Mueller Spec. Publ. Ser., this volume, 2009.

Mal'kov, B. I.: Scheme of development of the southeastern part of the Yana-Kolyma geosynclinal system, in Mesozoic Tectonogenesis, SVKNII DVO AN SSSR, Magadan, 43-50, 1971 (in Russian).

McLean, M. S., Fujita, K., Mackey, K. G., Kleber, E., Koz'min, B. M., and Imaev, V. S.: The Ulakhan fault system, northeast Russia, EOS T. Am. Geophys. Un., 81(48), suppl., F1164, 2000.

McMullen, C. A.: Seismicity and Tectonics of the Northeastern Sea of Okhotsk, M.S. thesis, Michigan State University, East Lansing, 1985.

Minster, J. B., Jordan, T. H., Molnar, P., and Haines, E.: Numerical modeling of instantaneous plate tectonics, Geophys. J. Roy. Astr. S., 36, 541-576, 1974.

Misharina, L. A.: Stresses in the Earth's Crust in Rift Zones, Nauka, Moscow, 1967 (in Russian).

Mushketov, I. and Orlov, A.: Catalog of Earthquakes of the Russian Empire, Tipografiya Imperatorskoi Akademii Nauk, Sankt Peterburg, 1893 (in Russian).

Nokleberg, W. J., Parfenov, L. M., Monger, J. W. H., Norton, I. O., Khanchuk, A. I., Stone, D. B., Scotese, C. R., Scholl, D. W., and Fujita, K.: Phanerozoic tectonic evolution of the cicum-north Pacific, US Geol. Surv. Prof. Pap. 1626, 2000.

Odinets, M. G.: The problem of the contamination of the earthquake catalog of the Northeast with data on industrial explosions, in: Geophysical Models of Geological Processes in Northeastern Russia, edited by: Lin'kova, T. I. and Bobrovnikov, V. A., SVKNII DVO RAN, Magadan, 90-99, 1996 (in Russian).

Okal, E. A. and Talandier, J.: Mm: A variable-period mantle magnitude, J. Geophys. Res., 94, 4169-4193, 1989.

Olson, D. R.: The Eurasian - North American Plate Boundary Through the Area of the Laptev Sea, M.S. thesis, Michigan State University, East Lansing, 1990.

Paech, H.-J., Prokopiev, A. V., v. Gosen, W., Grinenko, O. V., Smetannikova, I., and Belolyubskij, I. N.: New results of the Moma rift system and coeval structures in Yakutia, Polarforschung, 68, 59-63, 1998 (issued 2000).

Parfenov, L. M.: Tectonics of the Verkhoyansk-Kolyma Mesozoides in the context of plate tectonics, Tectonophysics, 199, 319-342, 1991.

Parfenov, L. M., Koz'min, B. M., Imaev, V. S., Boldyrev, M. V., Bocharov, G. V., Grinenko, O. V., Dudko, E. A., Zamaraev, N. N., Imaeva, L. P., Petrov, A. F., and Suvorov, V. D.: Geodynamics of the Olekma-Stanovoi Seismic Zone, Yakutskii Filial SO AN SSSR, Yakutsk, 1985 (in Russian).

Parfenov, L. M., Koz'min, B. M., Imayev, V. S., and Savostin, L. A.: The tectonic character of the Olekma-Stanovoy seismic zone, Geotectonics, 21, 560-572, 1987.

Parfenov, L. M., Koz'min, B. M., Grinenko, O. V., Imaev, V. S., and Imaeva, L. P.: Geodynamics of the Chersky seismic belt, J. Geodyn., 9, 15-37, 1988.

Pedoja, K., Bourgeois, J., Pinegina, T., and Higman, B.: Does Kamchatka belong to North America? An extruding Okhotsk block suggested by coastal neotectonics of the Ozernoi Peninsula, Kamchatka, Russia, Geology, 34, 353-356, 2006.

Peltzer, G. and Tapponnier, P.: Formation and evolution of strikeslip faults, rifts, and basins during the India-Asia collision: an experimental approach, J. Geophys. Res., 93, 15 085-15 117, 1988.

Piskarev, A. L., Roeser, H. A., Hinz, K., and Kos'ko, M. K.: Potential field studies on the crustal structure of the Laptev Sea and the western part of the East Siberian Sea, Polarforschung, 69, 41-50, 1999 (issued 2001)

Prokop'ev, A. V.: Kinematics of Mesozoic Folding in the Western Part of the Southern Verkhoyansk, Yakutskii Nauchnyi Tsentr SO AN SSSR, Yakutsk, 1989 (in Russian).

Rautian, T. G.: Attenuation of seismic waves and the energy of earthquakes I, Trudy Instituta Seismostoikogo Stroitel'stva i Seismologii Akademii Nauk Tadzhiksoi SSR, 7, 41-85, 1958 (in Russian).

Rautian, T. G., Khalturin, V. I., Fujita, K., Mackey, K. G., and Kendall, A. G.: Origins and methodology of the Russian energy $\mathrm{K}$-class system and its relationship to magnitude scales, Seismol. Res. Lett., 78, 579-590, 2007.

Riegel, S. A.: Seismotectonics of Northeast Russia and the Okhotsk Plate, M.S. thesis, Michigan State University, East Lansing, 1994.

Riegel, S. A., Fujita, K., Koz'min, B. M., Imaev, V. S., and Cook, D. B.: Extrusion tectonics of the Okhotsk plate, northeast Asia, Geophys. Res. Lett., 20, 607-610, 1993.

Rowley, D. B. and Lottes, A. L.: Plate-kinematic reconstructions of the North Atlantic and Arctic: Late Jurassic to Present, Tectonophysics, 155, 73-120, 1988.

Rudich, K. N.: Late Quaternary volcano Balagan-Tas, in: Presentday Volcanism in Northeast Siberia, edited by: Rudich, K. N., Nauka, Moscow, 3-44, 1964 (in Russian).

Savostin, L. A. and Baranov, B. V.: Interaction of the Amur and Okhotsk microplates near Sakhalin, Dokl. Earth Sci., 259, 6164, 1981

Savostin, L. A. and Drachev, S. S.: Cenozoic compression in the vicinity of the Novosibirsky Islands and its relationship to the opening of the Eurasia basin, Oceanology, 28, 601-606, 1988.

Savostin, L. A. and Karasik, A. M.: Recent plate tectonics of the Arctic basin and of northeastern Asia, Tectonophysics, 74, 111$145,1981$. 
Savostin, L. A., Verzhbitskaya, A. I., and Baranov, B. V.: Presentday tectonics of the Sea of Okhotsk plate region, Dokl. Akad. Nauk SSSR+, 266, 961-965, 1982 (in Russian).

Savostin, L., Zonenshain, L., and Baranov, B.: Geology and plate tectonics of the Sea of Okhotsk, Amer. Geophys. Un. Geodyn. Ser., 11, 189-221, 1983.

Savostin, L. A., Karasik, A. M., and Zonenshayn, L. P.: The history of the opening of the Eurasia basin in the Arctic, Dokl. Earth Sci., 275, 79-83, 1985.

Sella, G. F., Dixon, T. H., and Mao, A.: REVEL: A model for Recent plate velocities from space geodesy, J. Geophys. Res., 107(B4), 2081, doi:10.1029/2000JB000033, 2002.

Şengör, A. M. C., Görür, N., and Şaroğlu, F.: Strike-slip faulting and related basin formation in zones of tectonic escape: Turkey as a case study, Soc. Econ. Paleontol. Mineral. Spec. Publ. 37, 227-264, 1985.

Seno, T., Sakurai, T., and Stein, S.: Can the Okhotsk plate be discriminated from the North American Plate?, J. Geophys. Res., 101, 11 305-11315, 1996.

Smirnov, V. N.: Orogenic Regions, northeast Eurasia, in: Neotectonics, Geodynamics, and Seismicity of Northern Eurasia, edited by: Grachev, A. F., PROBEL, Moscow, 120-133, 2000 (in Russian).

Solov'ev, S. I., Oskorbin, L. S., and Ferchev, M. D.: Earthquakes of Sakhalin, Nauka, Moscow, 1967 (in Russian).

Stauder, W.: The focal mechanism of earthquakes, Adv. Geophys., 9, 1-76, 1962.

Steblov, G. M., Kogan, M. G., King, R. W., Scholz, C. H., Bürgmann, R., and Frolov, D. I.: Imprint of the North American plate in Siberia revealed by GPS, Geophys. Res. Lett., 30(18), 1924, doi:10.1029/2003GL017805, 2003.

Stein, S.: An earthquake swarm on the Chagos-Laccadive Ridge and its tectonic implications, Geophys. J. Roy. Astr. S., 55, 577588, 1978.

Stein, S. and Kroeger, G.: Estimating earthquake source parameters from seismological data, AMD, 42, 61-71, 1980.

Surkov, V. S., Larichev, A. I., Starosel'tsev, V. S., Sal'nikov, A. S., Sobolev, P. N., Migurskii, A. V., Lipilin, A. V., Mikhailov, B. K., Volkov, S. V., Fel'dman, L. L., Suleimanov, A. K., and Yakovlev, A. G.: Preliminary geologic results along the Magadan section of the exploratory geophysical profile 2-DV (Koni Peninsula Wrangel Island), in: Geodynamics, Magmatism and Mineragenesis of the Continental Margin of the Northern Pacific, edited by: Goncharov, V. I., SVKNII DVO RAN, Magadan, 1, 72-75, 2003 (in Russian).

Suvorov, V. D. and Kornilova, Z. A.: Thickness of the Earth's crust in the southeastern Verkhoyask-Kolyma fold system (according to near earthquakes), Tikhookean. Geol., 1986(4), 32-36, 1986 (in Russian).
Tapponnier, P., Peltzer, G., Le Dain, A. Y., Armijo, R., and Cobbold, P.: Propagating extrusion tectonics in Asia: new insights from simple experiments with plasticine, Geology, 10, 611-616, 1982.

Tarr, A. C.: New maps of polar seismicity, B. Seismol. Soc. Am., 60, 1745-1747, 1970.

Vazhenin, B. P.: Paleo-seismodislocations in the Chersky seismic belt, in: Seismologic and Petrophysical Investigations in Northeast Russia, edited by: Lin'kova, T. I., SVKNII DVO RAN, Magadan, 79-102, 1992 (in Russian).

Vazhenin, B. P.: Principles, Methods and Results of Paleoseismological Investigations in Northeast Russia, SVKNII DVO RAN, Magadan, 2000 (in Russian).

Vinnik, L. P. and Yegorkin, A. V.: Wave fields and lithosphereasthenosphere models from seismic observation data in Siberia, Dokl. Earth Sci., 250, 11-15, 1982.

Vinogradov, A. P. (Ed.): Atlas of the LithologicalPaleogeographical Maps of the USSR, GUGK Ministerstva Geologii SSSR, Moscow, 55 sheets, 1967 (in Russian).

Vinogradov, V. A., Kogan, A. L., and Shimaraev, V. N.: Results of regional seismic investigations in the southeastern part of the Laptev Sea, Geol. Geofiz., 33(6), 113-118, 1992 (in Russian).

Vladimirova, L. V., Vorob'eva, L. A., Efremova, L. V., Smirnov, V. N., Chepkunas, L. S., Shurshikov, V. S., and Yugova, R. S.: Kupka earthquake of 8 November, 1981, in: Seismic Processes in the Northeast USSR, edited by: Izmailov, L. I. and Lin'kova, T. I., SVKNII DVO AN SSSR, Magadan, 39-53, 1984 (in Russian).

Vogt, P. R., Taylor, P. T., Kovacs, L. C., and Johnson, G. L.: Detailed aeromagnetic investigation of the Arctic basin, J. Geophys. Res., 84, 1071-1089, 1979.

Voskresenskii, S. S., Kolosova, G. N., Polosukhina, Z. M., and Postolenko, G. A.: Paleogeography of the Seimchan-Buyunda basin in the Neogene and Quaternary periods, Vestn. Mosk. U. Geogr., 1973(6), 53-63, 1973 (in Russian).

Wilson, J. T.: Hypothesis of Earth's behaviour, Nature, 198, 925929, 1963.

Worrall, D. M., Kruglyak, V., Kunst, F., and Kuznetsov, V.: Tertiary tectonics of the Sea of Okhotsk, Russia: Far-field effects of the India-Eurasia collision, Tectonics, 15, 813-826, 1996.

Yudin, S. S. and Izmailov, L. I.: The Chelomdzha-Yamsk deep fault, Dokl. Earth Sci., 166, 93-95, 1966.

Zobin, V. M. and Simbireva, I. G.: Focal mechanisms of earthquakes in the Kamchatka-Commander region and heterogeneities of the active seismic zone, Pure Appl. Geophys., 115, 284-299, 1977.

Zonenshayn, L. P., Natapov, L. M., Savostin, L. A., and Stavskii, A. P.: Recent plate tectonics of northeastern Asia in connection with the opening of the North Atlantic and the Arctic Ocean basins, Oceanology, 18, 550-555, 1978. 